\title{
Exploring the nature of air quality over southwestern Ontario: main findings from the Border Air Quality and Meteorology Study
}

\author{
J. R. Brook ${ }^{1}$, P. A. Makar ${ }^{1}$, D. M. L. Sills ${ }^{2}$, K. L. Hayden ${ }^{1}$, and R. McLaren ${ }^{3}$ \\ ${ }^{1}$ Air Quality Research Division, Environment Canada, Toronto ON, Canada \\ ${ }^{2}$ Cloud Physics and Severe Weather Research Section, Environment Canada, Toronto ON, Canada \\ ${ }^{3}$ Centre for Atmospheric Chemistry, York University, Toronto ON, Canada
}

Correspondence to: J. R. Brook (jeff.brook@ec.gc.ca)

Received: 13 March 2013 - Published in Atmos. Chem. Phys. Discuss.: 24 April 2013

Revised: 3 September 2013 - Accepted: 10 September 2013 - Published: 29 October 2013

\begin{abstract}
This paper serves as an overview and discusses the main findings from the Border Air Quality and Meteorology Study (BAQS-Met) in southwestern Ontario in 2007. This region is dominated by the Great Lakes, shares borders with the United States and consistently experiences the highest ozone $\left(\mathrm{O}_{3}\right)$ and fine particulate matter concentrations in Canada. The purpose of BAQS-Met was to improve our understanding of how lake-driven meteorology impacts air quality in the region, and to improve models used for forecasting and policy scenarios. Results show that lake breeze occurrence frequencies and inland penetration distances were significantly greater than realized in the past. Due to their effect on local meteorology, the lakes were found to enhance secondary $\mathrm{O}_{3}$ and aerosol formation such that local anthropogenic emissions have their impact closer to the populated source areas than would otherwise occur in the absence of the lakes. Substantial spatial heterogeneity in $\mathrm{O}_{3}$ was observed with local peaks typically $30 \mathrm{ppb}$ above the regional values. Sulfate and secondary organic aerosol (SOA) enhancements were also linked to local emissions being transported in the lake breeze circulations. This study included the first detailed evaluation of regional applications of a high-resolution ( $2.5 \mathrm{~km}$ grid) air quality model in the Great Lakes region. The model showed that maxima in secondary pollutants occur in areas of convergence, in localized updrafts and in distinct pockets over the lake surfaces. These effects are caused by lake circulations interacting with the synoptic flow, with each other or with circulations induced by urban heat islands. Biogenic and anthropogenic emissions were both shown to play a role in the formation of SOA in the region. Detailed particle measurements and multivariate receptor models reveal that while
\end{abstract}

individual particles are internally mixed, they often exist within more complex external mixtures. This makes it difficult to predict aerosol optical properties and further highlights the challenges facing aerosol modelling. The BAQSMet study has led to a better understanding of the value of high-resolution $(2.5 \mathrm{~km})$ modelling for air quality and meteorological predictions and has led to several model improvements.

\section{Introduction}

During the summer of 2007, the Border Air Quality and Meteorology Study (BAQS-Met) was conducted in order to examine the influence of meteorology on air quality in southwestern Ontario, Canada. The study was motivated by the fact that this region experiences the poorest air quality in Canada, which is significantly influenced by international trans-boundary transport and complex meteorology in the vicinity of the Great Lakes. An improved understanding of these factors is required to better forecast pollutant concentrations and severe weather and to develop effective strategies to improve air quality, human health, environmental impacts, and to reduce the significant associated costs (DSS, 2005).

The Canada/USA border region where the study took place is densely populated, industrialized and urbanized. At the western edge of the region lie the major populated industrial cities of Detroit, MI and Windsor, ON, linked by the busiest international border crossing between Canada and the US. A string of industries and power plants extend from 
south of these cities (e.g., Toledo, $\mathrm{OH}$ ) to the north along the St. Clair River ending in Sarnia, ON, home to the largest concentration of petrochemical facilities in Canada. The region is in close proximity to the largest concentration of coal fired power plants in North America, the Ohio River Valley. Consequently, emissions of nitrogen oxides and sulfur oxides in this region are large (McGuire et al., 2011; Halla et al., 2011).

BAQS-Met was led by Environment Canada and involved scientists from the Canadian federal and Ontario provincial governments, along with scientists from four universities. York University led the academic involvement with collaboration from the University of Toronto, the University of Western Ontario and the University of Windsor. While the majority of scientists were from the field of air quality research, a unique aspect of the study was the involvement of meteorological researchers with expertise in Great Lakes meteorology and severe weather.

The BAQS-Met special issue of Atmospheric Chemistry and Physics contains 20 research papers (Chan et al., 2011; Ellis et al., 2011; Flagg and Taylor, 2011; Halla et al., 2011; Hayden et al., 2011; He at al., 2011; Lee et al., 2011; Levy et al., 2010; Jeong et al., 2010, 2011; Makar et al., 2010a, b; Markovic et al., 2011; McGuire et al., 2011; Sills et al., 2011; Sjostedt et al., 2011; Slowik et al., 2011; Stroud et al., 2011, 2012; Wentzell et al., 2010) covering aspects of regional particle physics, chemistry and source apportionment, secondary organic and inorganic particle formation, the influence of the lakes on ozone and particles; lake breeze kinematics and behaviour, remote measurements (surface and satellite) of $\mathrm{NO}_{2}$ and $\mathrm{AOD}$ and high-resolution meteorological modelling of regional air quality. The intent of the current paper is to describe the objectives and the main hypotheses considered by the BAQS-Met study and the main results. This paper discusses the motivation for conducting a study in southwestern Ontario, the study design and conditions during the measurement period, and then provides a synthesis of results from the papers in the special issue in the context of the original study hypotheses and main conclusions.

\section{Air quality issues and observations in southwestern Ontario}

Southern Ontario experiences the highest ground-level ozone $\left(\mathrm{O}_{3}\right)$ levels in Canada. Prior to the BAQS-Met study, $\mathrm{O}_{3}$ concentrations exceeded the Canadian Canada Wide Standard (CWS), throughout the BAQS-Met study region (Environment Canada, 2011). Specifically, from 2004-2006, the running three-year averages of the annual 4th highest daily $8 \mathrm{~h}$ maximum mixing ratio exceeded the CWS of $65 \mathrm{ppb}$ at a majority of the monitoring sites (Ontario, 2004, 2005, 2006). Despite the relatively dense monitoring coverage in southern Ontario, there remain many unmonitored areas, including over the Lakes. Measurements and model predictions are combined in Fig. 1 to better characterize the spatial pat- tern in the $8 \mathrm{~h}$ daily maximum $\mathrm{O}_{3}$ for May-September of 2004-2006. This synthesis shows $8 \mathrm{~h} \mathrm{O}_{3}$ exceeding $60 \mathrm{ppb}$ over Lake Erie and coastal locations. This is in accord with prior model simulations that show episodically high $\mathrm{O}_{3}$ levels (Reid et al., 1996; Hastie et al., 1999; Fosco and Schmeling, 2006) over the Great lakes (e.g., Garcia et al., 2010; Fann et al., 2012). Long-term measurements over the Lakes are generally not available to verify these projected levels. Figure 1 shows that $\mathrm{O}_{3}$ is elevated even over more northern parts of the lakes. As there are no major cities or significant industrial regions along the shoreline in these areas, this strongly suggests that the source of elevated $\mathrm{O}_{3}$ concentrations is regional transport over the lakes. The preferential transport of $\mathrm{O}_{3}$ and other pollutants over the Great Lakes, as opposed to the land surface, has been understood for some time (e.g., Lyons and Cole, 1973, 1976; Sillman et al., 1993; Lyons et al., 1995a, b). The phenomenon is a consequence of decoupling of the air above the water from the mixed layer via the formation of a shallow inversion above the cool water, which prevents vertical mixing. The relative scarcity of emission sources over water compared to land also reduces scavenging of $\mathrm{O}_{3}$ by $\mathrm{NO}$ except in areas impacted by ship emissions. Combined with a lower deposition velocity for $\mathrm{O}_{3}$ over water compared to terrestrial surfaces, the net result is a relative enhancement of the lifetime of $\mathrm{O}_{3}$ over water with the potential for transport to receptors onshore. At night, reservoirs of $\mathrm{O}_{3}$ may persist preferentially over the lakes. The nighttime land breeze can also transport pollutants emitted and/or formed over land into the stable layer over the lakes where they remain near the coast and trapped close to the surface. Thus it is clear that the Great Lakes are an important physical feature influencing air quality in the region. While it is well known that the Lakes modify the meteorology in the boundary layer due to differences in the sensible heat flux over land and water, mechanisms by which the Lakes impact chemical processes (e.g., change in precursor mixes, changes in radical concentrations) are not understood.

The Lakes are known to suppress clouds behind lake breeze fronts and enhance cloud development along them, sometimes leading to thunderstorm development. The area northeast of Lake St. Clair, a region where multiple lake breeze fronts frequently interact, experiences the highest lightning flash density (flashes $\mathrm{km}^{-2} \mathrm{yr}^{-1}$ ) in Canada (Burrows and Kochtubajda, 2010). The influence of lake-breeze circulations on severe thunderstorm formation in this region has therefore been the subject of several past studies (King et al., 2003; Sills et al., 2002; King and Sills, 1998; Sills, 1998). This enhanced deep convection "overturns" the atmosphere, potentially having a significant impact on air quality (Dickerson et al., 1987). Clouds generated by updrafts at lake-breeze fronts can also be regions of active aqueous phase chemistry influencing aerosol formation and composition (Hayden et al., 2008).

Numerous studies of the interaction between air pollutant emissions and meteorology have been conducted in coastal 
areas across the globe (e.g., Lu and Turco, 1994; Steyn et al., 1997; Hedley et al., 1997; Millán et al., 1996, 2000; Seaman and Michelson, 1998; Grossi et al., 2000; Cheng, 2002; Boucouvala and Bornstein, 2003; Brook et al, 2004; Evtyugina et al., 2006; Levy et al., 2008; McLaren et al., 2010; Smoydzin et al., 2012; Parrish et al., 2009). Like the Great Lakes region, these studies consistently show that spatial heterogeneity in pollutant levels can be large over relatively short distances and that local, thermally driven circulations play a role in pollutant movement. They also show that when sea or lake breezes progress inland they cause a shallow temperature inversion over the land near the coastline suppressing vertical mixing of pollutants. This progression also tends to carry more polluted air inland during which time secondary pollutants may form, increasing $\mathrm{O}_{3}$ concentrations at downwind locations for example. At the leading edge of the sea- or lake-breeze front, highly complex vertical motions occur. On multiple scales, the pollutant patterns that result are strongly influenced by the direction and strength of the synoptic winds and their interaction with the sea or lake breeze. Furthermore, other factors influence air pollutant transport in these areas, such as terrain, coastal configuration, and the spatial and temporal nature of the local emissions. It is difficult to apply what is learned in one location to other areas (Barros et al., 2003) because the most influential factors differ from one region to another.

Of considerable interest is the occurrence of enhanced pollutant concentrations behind the lake-breeze front when it moves onshore. In particular, enhancements in $\mathrm{O}_{3}$ concentration are often seen with the passage of a lake-breeze front during the day (Reid et al., 1996; Hastie et al., 1999). If these enhancements are due to local emissions of ozone precursors, then there are two likely explanations. Either a land breeze or drainage flow transports pollutants over the water the previous night, or a return flow associated with a lake-breeze circulation moves terrestrial precursor pollutants over the water. Both of these mechanisms imply that the local emissions are recirculating, having a greater impact on the region by increasing the lifetime that the precursor emissions spend in the region. Many modelling studies have provided evidence that recirculation can occur (e.g., Lu and Turco, 1994; Eastman et al., 1995; Ma and Lyons, 2003; Harris and Kotomarthi, 2005) as have analyses of observations (Lyons and Olson, 1973; Levy et al., 2008). Most studies conducted in oceanic coastal regions have concluded that $\mathrm{O}_{3}$ maxima on days with active photochemistry are due to formation on that day, as opposed to multi-day recirculations (e.g., Houston, New Zealand, Taiwan (Cheng, 2002), Persian Gulf, Los Angeles (Blumenthal et al., 1978), Athens (Kambezidis et al., 1998), Portugal (Evtyugina et al., 2006)). When sea breezes occur in mountainous areas (e.g., Barcelona, Los Angeles, Vancouver) there is a higher probability for previous day pollutants to remain in the area given the formation of residual layers aloft which can mix downward on subsequent days or move offshore, subside and return inland (e.g., Lu and Turco, 1994; Millán et al., 1996; McKendry and Lundgren, 2000). However, the relative importance of multi-day $\mathrm{O}_{3}$ accumulating over the water versus same day formation in the Great Lakes region has not been adequately explored. Increasing our understanding of the role of these meteorological processes is thus important in explaining relatively high $\mathrm{O}_{3}$ concentrations observed in parts of the Great Lakes region.

Much less information on the impact of the lakes and meteorological circulations on $\mathrm{PM}_{2.5}$ is available, though some processes may be inferred from known meteorology. Secondary aerosol formation can be expected to be influenced through retention of precursors in a concentrated surface layer with enhanced solar radiation due to subsiding air and cloud suppression over the lakes, and potentially through increased water vapor. These conditions may also concentrate primary $\mathrm{PM}_{2.5}$ over the lakes. Both primary and secondary $\mathrm{PM}_{2.5}$ may then be transported to coastal locations via lake breezes. Earlier Great Lakes studies, as referenced above, lacked instrumentation for time-resolved measurements of particle chemical composition and size. BAQS-Met thus represented an opportunity to explore these processes, given recent developments in particle measurement technology.

Concentrations of $\mathrm{PM}_{2.5}$ in southwestern Ontario routinely have a high regional background during the summer (Brook et al., 2002) and are consistently the highest in Canada (Government of Canada, 2012). There is one longterm, filter-based $\mathrm{PM}_{2.5}$ measurement site within the BAQSMet study area located in west Windsor. At this site, the median $24 \mathrm{~h} \mathrm{PM}_{2.5}$ for 2003-2008, was $14 \mu \mathrm{g} \mathrm{m}^{-3}$ and the 98th percentile was $36 \mathrm{\mu g} \mathrm{m}^{-3}$ (Dabek-Zlotorzynska et al., 2011). Maximum $24 \mathrm{~h}$ concentrations of $60 \mathrm{\mu g} \mathrm{m}^{-3}$ have been observed at this site. Southern Ontario locations that are likely most impacted lack filter-based $\mathrm{PM}_{2.5}$ monitoring, but are reasonably well-covered by monitoring sites utilizing the Tapered Element Oscillating Microbalance (TEOM) instrument (Ontario, 2006). These measurements, when adjusted for loss of semi-volatile compounds in the winter months (e.g., ammonium nitrate), indicate that prior to 2007, $\mathrm{PM}_{2.5}$ levels above the CWS were widespread (Government of Canada, 2012; Brook et al., 2013). This included Windsor, London and Sarnia, all within the BAQS-Met region. Sarnia had the highest annual $\mathrm{PM}_{2.5}$ in Canada during 2004-2006 with a mean concentration of $15 \mu \mathrm{g} \mathrm{m}^{-3}$ (Ontario, 2007; Government of Canada, 2012) This city's proximity to Detroit, Windsor, local coal-fired power plants and petrochemical facilities likely explains the high $\mathrm{PM}_{2.5}$ levels.

\section{Overview of the BAQS-Met study}

\subsection{Scientific hypotheses for BAQS-Met}

The main objective of BAQS-Met was to improve our understanding of and our ability to model the processes influencing air quality in the Great Lakes region. To guide the 
development of field study plans, a series of testable hypotheses were proposed:

1. The relative importance of local emissions on air quality is enhanced due to the presence of the Great Lakes.

2. Vertical motions induced by lake-breeze circulations and other surface-related features play a significant role in the transport and chemistry of pollutants and the initiation of thunderstorms in the Great Lakes area.

3. The accuracy of air quality and weather forecasting for southwestern Ontario is significantly impacted by how well the models and the weather data assimilation system treat these processes over and near the Great Lakes.

Enhanced importance of local emissions (Hypothesis 1) has implications for how to improve air quality over southern Ontario and is expected to result from two influences. The first is both chemical and physical in nature whereby the cool lakes give rise to a shallow and stable surface layer which confines local emissions for longer periods of time. Solar radiation is enhanced due to suppressed cloud formation, mixing/dispersion is limited and this extends the time for secondary chemical reactions to occur within the region. The Lakes also re-circulate the local emissions trapped over the lake surface. Overall, the above conditions are hypothesized to lead to greater photochemical processing of urban emissions close to the source area. The second influence is dynamical in that the lake-induced circulation affects local air quality through physical transport of air pollutants with conditions over the lake suppressing dry deposition.

\subsection{Design of the BAQS-Met study}

The BAQS-Met field campaign consisted of two components: an intensive period (IP) from 20 June to 10 July 2007, inclusive, and an extended period (EP or "mesonet") from June to September, 2007, during which an enhanced measurement network was in place for both meteorological and air pollutant measurements. This two component approach was helpful to diagnose process-level differences in $\mathrm{O}_{3}$ and $\mathrm{PM}_{2.5}$ accumulation and formation under the influence of the Lakes, evolution of pollutants downwind of the Detroit/Windsor metropolis, and the influence of lake-breeze front updrafts on the vertical transport of pollutants and the development of thunderstorms. The dates of the IP were selected to coincide with the time of year during which the region experiences the highest $\mathrm{O}_{3}$ concentrations, the greatest insolation (i.e., summer solstice) and the largest landwater temperature differences, thereby increasing the probability of lake-breeze circulations. For both components of the study, air pollutant and meteorological measurements were obtained at multiple fixed sites with the IP enhanced by three supersites and measurements from land-based, water-based and airborne mobile platforms.

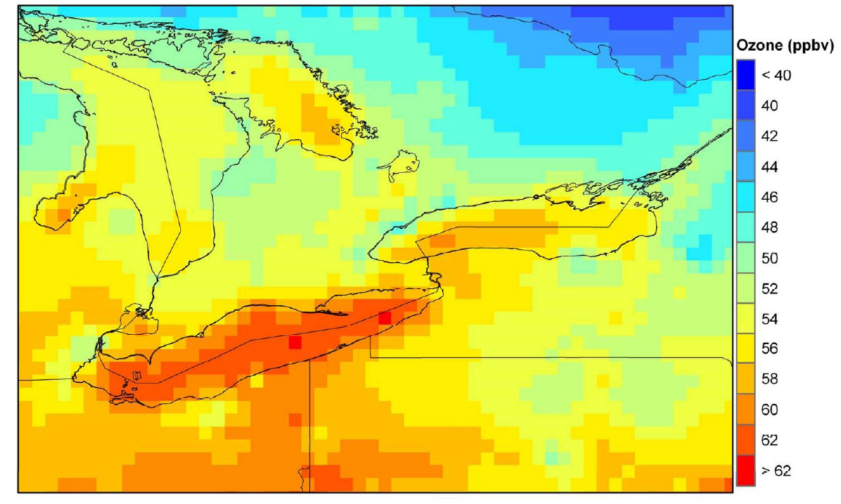

Fig. 1. Model + measurement objective analysis of the three-year average (2004-2006) warm season daily $8 \mathrm{~h}$ maximum $\mathrm{O}_{3}$ over southern Ontario. This map is based upon work by Robichaud and Ménard (2013) and was produced from hourly $\mathrm{O}_{3}$ predictions across a $21 \mathrm{~km}$ grid from the former Canadian air quality forecasting model, CHRONOS, with meteorology reinitialized every $24 \mathrm{~h}$, and hourly $\mathrm{O}_{3}$ observations across Canada and the US. An optimal interpolation approach based upon a least squares combination of the CHRONOS and $\mathrm{O}_{3}$ data that minimized the error variance was used hour by hour for the months of May through September of each of the three years.

\subsubsection{Fixed sites}

Figure 2a shows the 15 federal, state and provincial $\mathrm{O}_{3}$ monitoring sites in operation in the region. There were also several meteorological sites in existence as well as a number of hourly/continuous $\mathrm{PM}_{2.5}$ monitoring sites. To enhance the coverage provided by these sites, grid point locations from the Meteorological Service of Canada's $15 \mathrm{~km}$ weather forecast model were used to site 16 additional surface stations, comprising a three-month mesonet. This included a meteorological buoy on Lake St. Clair and a buoy for both meteorological and air pollutant measurements on Lake Erie. The main goal was to have measurements in as many grids as possible and to have them separated by $15 \mathrm{~km}$. In total there were 54 meteorological sites during BAQS-Met, as shown in Sills et al. (2011, Fig. 1).

Eight of the mesonet sites had $5 \mathrm{~min} \mathrm{O}_{3}$ measurements (2B Technology) and the Lake Erie buoy had $1 \mathrm{~min}_{3}$ measurements (Thermo Environmental). Seven of these locations had a complete data record for a majority of the three-month study period, while partial data records were obtained at the other sites. An additional provincial monitoring site reporting $\mathrm{O}_{3}, \mathrm{NO}, \mathrm{NO}_{\mathrm{x}}$ and $\mathrm{PM}_{2.5}$ was installed on Pelee Island in Lake Erie for the duration of the mesonet operation. Passive, two-week average $\mathrm{O}_{3}, \mathrm{NO}_{2}$ and $\mathrm{NH}_{3}$ concentrations were measured using Ogawa samplers at all 16 mesonet sites, the West Windsor site and at the University of Windsor close to the international border crossing. The mesonet sites reporting $\mathrm{O}_{3}$ are shown in Levy et al. (2010) while the passive monitoring sites are shown in Lee et al. (2011). 


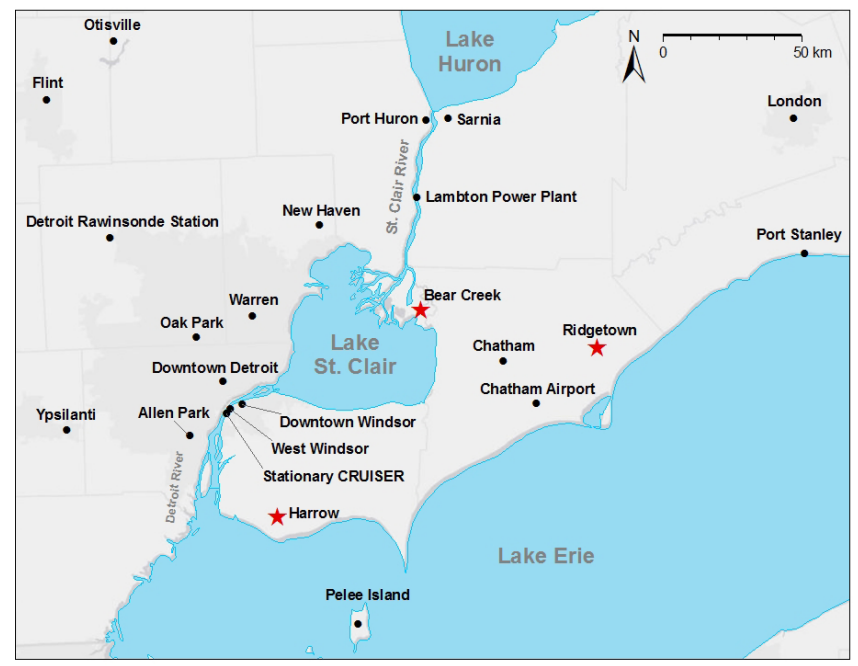

Fig. 2a. Map of the main BAQS-Met study region showing the locations of the three supersites (red star) and other geographic features of importance including all the routine ozone monitoring locations in southwestern Ontario and southeast Michigan.

During the IP, supersites were operated at Harrow, Bear Creek and Ridgetown with an enhanced suite of instrumentation (Fig. 2a). The Harrow site was selected for its location downwind of Windsor-Detroit under northwest flow and its potential for sampling regional background pollutants under southerly flow. Bear Creek was selected to provide regional background levels under northwest flow and urbanimpacted conditions with southwest flow. Ridgetown was located further east in a rural region $\sim 10 \mathrm{~km}$ north of the Lake Erie shoreline and more than $70 \mathrm{~km}$ from significant direct sources. This site was chosen to represent the regional background of southwestern Ontario under all flow regimes. Furthermore, its greater distance from the shoreline compared to Harrow was thought to be advantageous for the analysis of passages of Lake Erie lake-breeze fronts later in the day, allowing more time for chemical/physical evolution of the lake-breeze front gradient, and an examination of aging and oxidation contrast between these sites.

The instruments operated at the supersites are listed in Table 1. Vertical information was obtained at Harrow using ozonesondes released every $12 \mathrm{~h}$ (He et al., 2011), and via a wind profiler near Harrow (Hocking, 1997). Vertical information at Ridgetown was obtained via tethersonde profiling of $\mathrm{O}_{3}$ and meteorology on select days, a scanning LIDAR (Strawbridge and Snyder, 2004) and a MAX-DOAS system (Halla et al., 2011) for $\mathrm{NO}_{2}$ and Aerosol Optical Depth (AOD).

\subsubsection{Mobile measurement platforms}

The four mobile platforms operated during the study included an instrument package added to a motor vehicle ferry

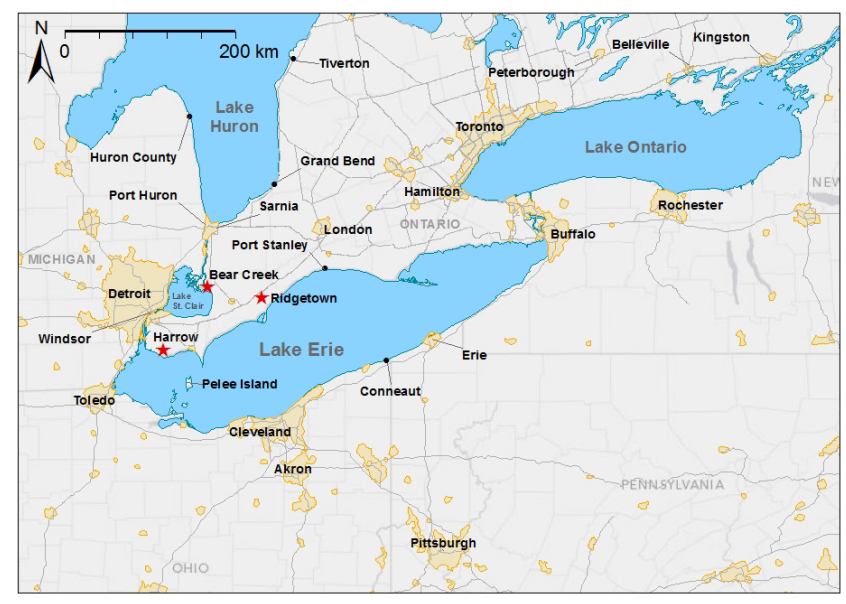

Fig. 2b. Map of the southern Great Lakes region showing the locations of the major cities in the region and all the ozone monitoring sites discussed in this paper.

operating on Lake Erie, a ground-based air quality mobile laboratory, a smaller ground-based meteorology research vehicle and a Twin Otter aircraft. Over-lake measurements of $\mathrm{O}_{3}, \mathrm{SO}_{2}$ and black carbon (BC) were made on the ferry during scheduled daily passages between Pelee Island and the mainland between mid June to late August (Levy et al., 2010). The Canadian Regional and Urban Investigation System for Environmental Research (CRUISER) mobile laboratory drove in the region for $4-10 \mathrm{~h} \mathrm{day}^{-1}$ during the intensive period following routes shown in Makar et al. (2010b). The routes were determined each morning based upon forecast meteorology and air quality. CRUISER was also used to obtain stationary measurements at night and on several days (a large fraction of the IP) while parked in west Windsor. The instruments on CRUISER are shown in Table 2. Instrumentation installed on Environment Canada's Automated Mobile Meteorological Observation System (AMMOS) was used to study meteorological variations in the vicinity of lake-breeze fronts and thunderstorm gust fronts, and to record conditions along transects between lake shores (Table 2). AMMOS drove more frequently than CRUISER as its deployment depended upon the meteorological forecast and the potential for thunderstorm development. On some days AMMOS and CRUISER drove in tandem to obtain concurrent transects across the study area.

The instrumented aircraft, National Research Council of Canada's Twin Otter, obtained measurements during 16 separate flights (Hayden et al., 2011). Past experience with and knowledge of lake-breeze circulations in southwestern Ontario (Sills, 1998; King and Sills, 1998; Sills et al., 2002; King et al., 2003), as well as payload limitations, informed decisions related to flight plans originating in London, Ontario. To maximize measurement time within the study region, the Chatham airport was used for refuelling and staging 
Table 1. Measurement equipment operated at the three supersites.

\begin{tabular}{|c|c|c|}
\hline Harrow & Bear Creek & Ridgetown \\
\hline 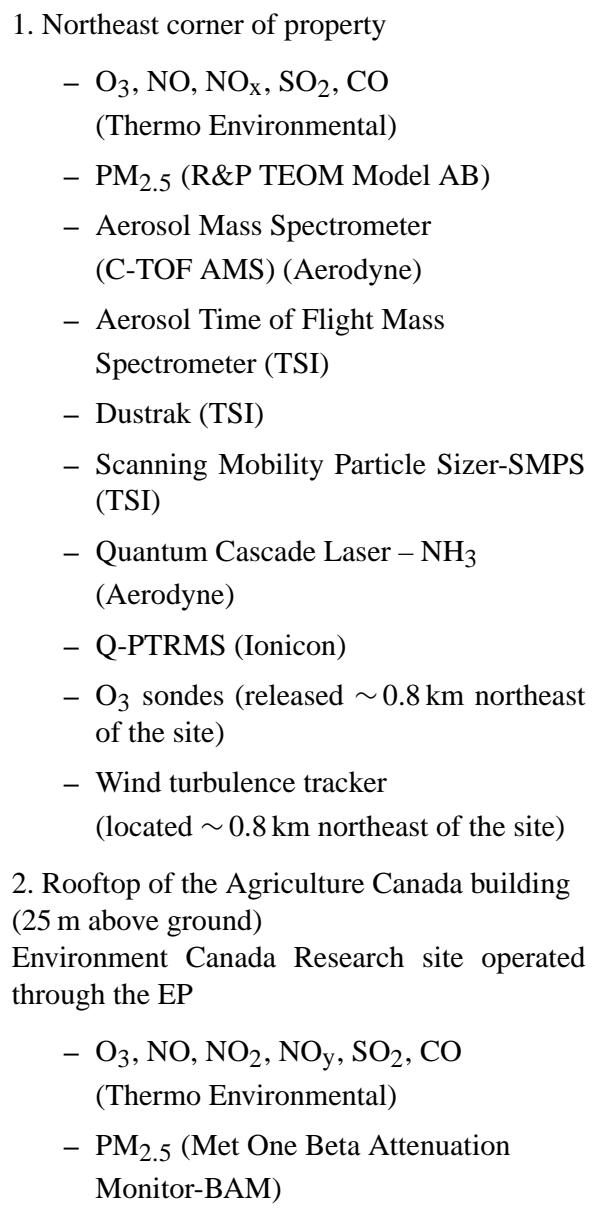 & 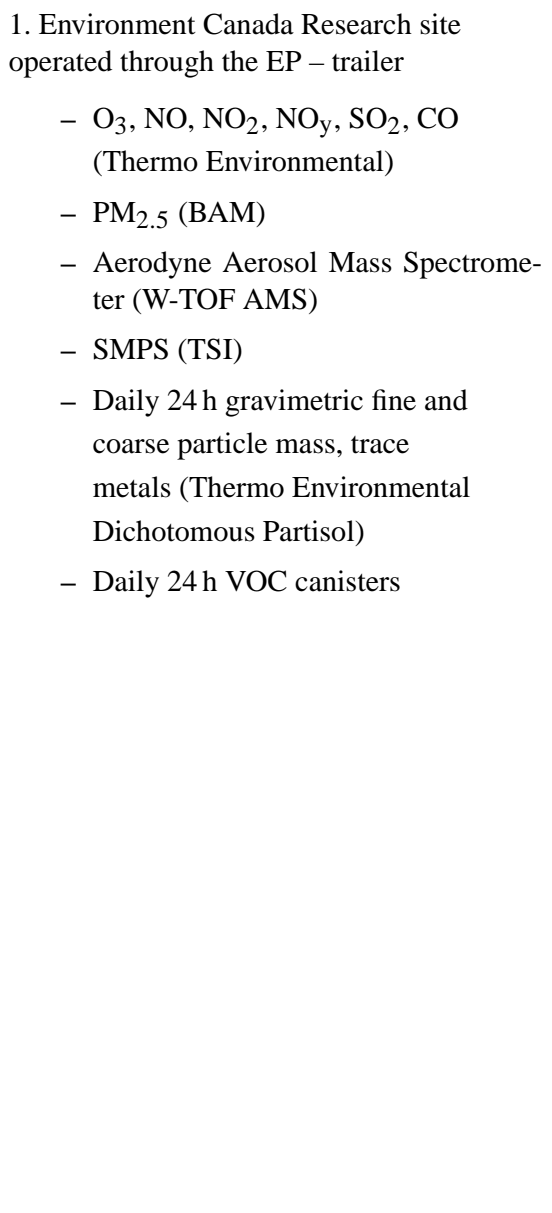 & 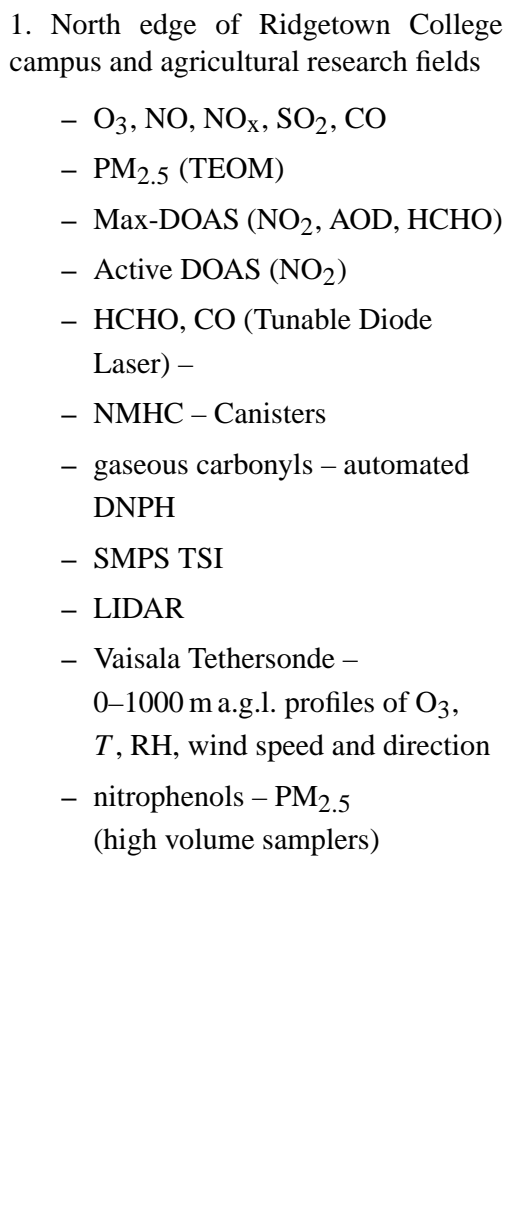 \\
\hline
\end{tabular}

Table 2. Description of the measurements made on board the mobile platforms operated during the intensive period of the study.

\begin{tabular}{|c|c|c|}
\hline Mobile air quality lab & Mobile meteorology lab & Aircraft \\
\hline $\begin{array}{l}\text { 1. Canadian Regional and Urban Investigation } \\
\text { System for Environmental Research } \\
\text { (CRUISER) } \\
\mathrm{NO}, \mathrm{NO}_{2}, \mathrm{NO}_{\mathrm{y}}(1 \mathrm{~Hz}) \text { (Thermo Environmental) } \\
\mathrm{O}_{3}, \mathrm{SO}_{2}, \mathrm{CO}(10 \mathrm{~s}) \text { (Thermo Environmental) } \\
\mathrm{PM}_{2.5}(5 \text { min when parked) (R\&P TEOM) } \\
\text { Aerosol Mass Spectrometer (Q-AMS) }_{(2-15 \mathrm{~min}) \text { (Aerodyne) }} \\
\mathrm{BC}\left(B_{\mathrm{abs}}\right)(1 \mathrm{~s}) \text { - Droplet Measurement Tech- } \\
\text { nologies photoaccoustic spectrometer } \\
\text { BC Soot Volume Fraction (SVC) (1 min) - } \\
\text { custom high sensitivity laser induced incandes- } \\
\text { cence (LII) } \\
\text { Meteorology (1 min when parked) - T, RH, } \\
\text { wind speed and direction, pressure (Climtronix) }\end{array}$ & $\begin{array}{l}\text { 1. Automated Mobile Meteorological Obser- } \\
\text { vation System (AMMOS) } \\
3.5 \mathrm{~m} \text { wind speed and direction } \\
2.5 \mathrm{~m} \text { aspirated temperature and relative } \\
\text { humidity } \\
2.5 \mathrm{~m} \text { pressure } \\
\text { GPS vehicle position, speed and orientation } \\
\text { Flux gate compass vehicle orientation } \\
\text { (when stopped) } \\
\text { All measurements } 1 \mathrm{~s} \text { samples } \\
\text { All measurements available when parked } \\
\text { All measurements also available when } \\
\text { mobile for selected days }\end{array}$ & $\begin{array}{l}\text { 1. National Research Council Twin Otter } \\
\mathrm{O}_{3}, \mathrm{NO}, \mathrm{NO}_{2}, \mathrm{SO}_{2}, \mathrm{CO} \\
\text { Aerodyne Aerosol Mass Spectrometer } \\
\text { (C-TOF AMS) } \\
\text { Particle Soot Absorption Photometer } \\
\text { (PSAP) } \\
\text { Condensation Nuclei Counter (TSI) } \\
\text { Passive Cavity Aerosol Spectrometer } \\
\text { Probe (DMT) } \\
\text { Meteorology }\end{array}$ \\
\hline
\end{tabular}




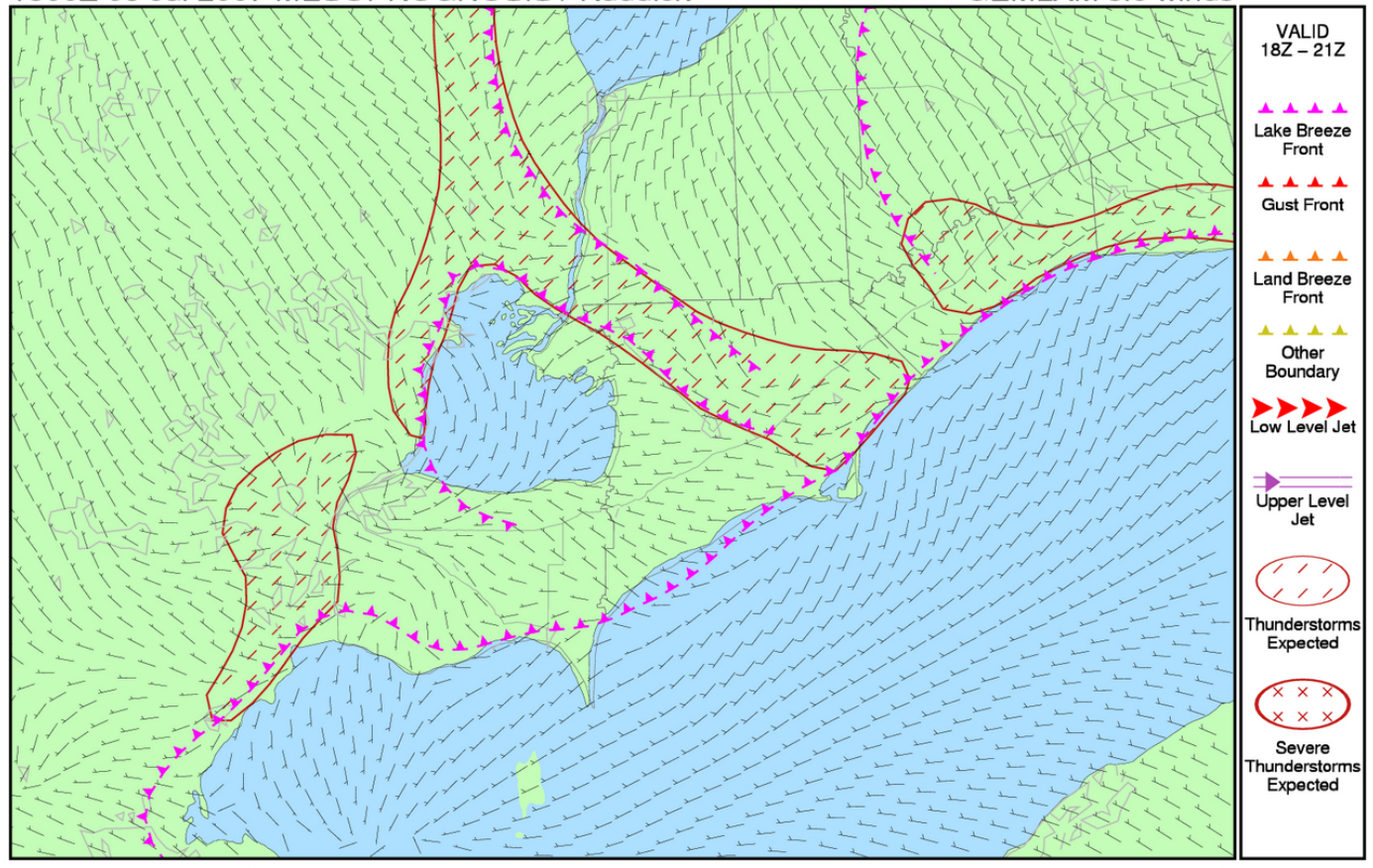

LOTS OF DRY AIR IN THE NWLY FLOW - XPCT SOME TCU DVLPMT ALG LAKE BREEZE ZONES AROUND $18 Z$ WITH SLIGHT CHC OF LOW TOPPED NON SVR TSTM. AMS WILL QUICKLY MIX OUT LATER THIS AFTN WITH CVCTN DSIPTG ERLY OVR BAQSMET AREA BY 21-22Z7.

Fig. 3. An example of a meteorological forecast product used to provide guidance for BAQS-Met field operations. The product shows the expected position of lake breeze fronts valid at 18:00 UTC/2 p.m. LT (magenta lines) and regions where thunderstorms are expected between 18:00 and 21:00 UTC/2 p.m. and 5 p.m. LT (red hatched areas) superimposed on the GEM high-resolution (2.5 km) predicted surface winds (shown in knots, long barb $=10 \mathrm{kt}$ and short barb $=5 \mathrm{kt}$ ).

when multiple flights per day were undertaken. Meteorological and air quality forecasts were used to select and refine the flight plan in advance of each flight.

The aircraft flights had four main objectives:

1. Characterize lake-breeze fronts and an entire lakebreeze circulation by obtaining vertical cross sections via stepped traverses, and/or multiple measurements of updraft velocity along the front (10 flights);

2. Obtain measurements of $\mathrm{O}_{3}$ and other pollutants at multiple heights over Lakes St. Clair and Erie, particularly at the lowest elevation ( $\sim 50 \mathrm{~m}$ ) (all flights);

3. Characterize the nocturnal urban boundary-layer over Detroit and vicinity (2 flights);

4. Examine the long-range transport of pollutants originating south of the region (3 flights).

\subsubsection{Real-time air quality and weather forecasting, and post-study modelling}

Both meteorological and air quality model runs and forecaster-generated weather forecast charts were used to plan the deployment of the mobile platforms and operation of the LIDAR, tethersonde and ozonesondes. The regional operational Global Environmental Multiscale meteorological model (GEM) provided $15 \mathrm{~km}$ resolution $48 \mathrm{~h}$ forecasts and limited-area $2.5 \mathrm{~km}$ resolution southern Ontario $24 \mathrm{~h}$ forecasts (Côté et al., 1998). Forecasters at a Research Support Desk at the Ontario Storm Prediction Centre in Toronto used the model guidance to help identify the most likely locations of lake-breeze fronts (valid 18:00 UTC/2 p.m. LT) and thunderstorms (valid 18:00-21:00 UTC/2-5 p.m. LT) for both the current day and the next day. An example of such a forecast product focused on the BAQS-Met study region is shown in Fig. 3. Hourly analyses using surface observations, radar and satellite data were also generated to assess confidence in the forecast.

All of the air-quality model simulations for BAQS-Met were carried out with the AURAMS model (Gong et al., 2006). Details on the air-quality modelling setup are described elsewhere (Makar et al., 2010b). Briefly, during the measurement intensive, an extra $48 \mathrm{~h}$ forecast run of the GEM meteorological model was carried out to provide weather forecasts and the driving meteorology for AURAMS, with both GEM and AURAMS operating at $15 \mathrm{~km}$ resolution over eastern North America. Surface and typical aircraft elevation concentration maps of $\mathrm{O}_{3}, \mathrm{PM}_{2.5}$ and other 
species, and forward and backward trajectories, were generated. On-site forecasters made use of the above information as well as standard forecast products to provide twice daily updates on current and expected conditions during the IP. This information was critical for decision making pertaining to flight planning and driving routes of CRUISER and AMMOS. Post-study analysis was carried out using highresolution meteorological and air-quality model runs with a three-level nesting of AURAMS; an outer domain $(42 \mathrm{~km}$ North American) driving a $15 \mathrm{~km}$ domain (eastern North American) driving a $2.5 \mathrm{~km}$ domain (centered on southwestern Ontario).

\subsection{Overview of conditions during the BAQS-Met study}

The $\mathrm{O}_{3}$ season (April-September) of 2007 had a large number of high $\mathrm{O}_{3}$ days (defined here as a daily hourly maximum $\geq 80 \mathrm{ppb}$ ) over southern Ontario compared to subsequent years (i.e., 2008-2011). Several episodes occurred prior to the IP and there were two periods during the IP. After the IP, a high $\mathrm{O}_{3}$ event occurred in early August followed by four high $\mathrm{O}_{3}$ days in September. The greatest number of high $\mathrm{O}_{3}$ days within the region (Fig. 2b) was 33, at a site $\sim 50 \mathrm{~km}$ southwest of Cleveland, OH. Other locations outside the intensive observation zone reporting high $\mathrm{O}_{3}$ days included a site northeast of Pittsburgh (29 days), and Conneaut, $\mathrm{OH}$, on the Lake Erie shoreline (28 days). The Conneaut observations (see Fig. $2 b$ for location of this site and others discussed below) are consistent with the expected high concentrations based upon past conditions near and over Lake Erie as shown in Fig. 1. High $\mathrm{O}_{3}$ concentrations were also reported downwind of the BAQS-Met region close to the Lake Ontario shoreline at Belleville (27 days) and Kingston (23 days). These cases were likely due to pollutant transport over the lake given that there were only five high $\mathrm{O}_{3}$ days relatively close by in Peterborough, which is only $100 \mathrm{~km}$ northwest of Belleville. Within the BAQS-Met study area, Port Stanley, on the north shore of Lake Erie, recorded 24 high $\mathrm{O}_{3}$ days. To the northwest, there were also a large number of events along Lake Huron, compared to inland sites in the area, implicating a lake-related effect (Grand Bend, 22 days; Sarnia, 20 days; Huron County, 20 days; Tiverton, 19 days).

More extreme $\mathrm{O}_{3}$ days $\left(\max 1 \mathrm{~h} \mathrm{O}_{3} \geq 100 \mathrm{ppb}\right.$ ) were observed at several sites. Grand Bend experienced the most with 9 days followed by: downtown Windsor/Detroit (7 days), Port Huron, MI, Akron, OH, and Tiverton, ON (5 days). Bordering the BAQS-Met region, Belleville and Conneaut both had 7 days of extreme $\mathrm{O}_{3}$. Throughout all of Ontario, Michigan, Ohio, Pennsylvania, New York and Indiana only one other site (located in suburban Philadelphia) had 9 days $\geq 100 \mathrm{ppb}$. Interestingly, two sites within the urban core of Windsor and Detroit had a large number of high $\mathrm{O}_{3}$ days, 24 and 26, respectively. This behaviour is generally unexpected since urban areas typically experience lower $\mathrm{O}_{3}$ levels due to titration by $\mathrm{NO}$ emissions. However, evi-

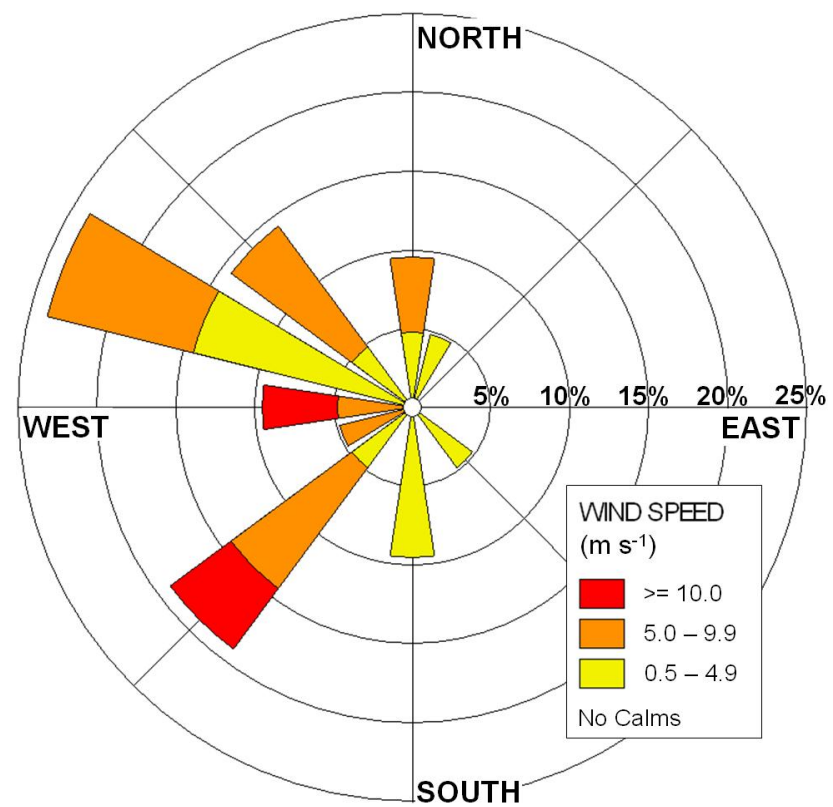

Fig. 4. Wind rose diagram showing the percent frequency of rawinsonde-derived $850 \mathrm{hPa}$ wind directions (16 bins) and wind speeds $($ light $=$ yellow, moderate $=$ orange, and strong $=$ red $)$ for 21 days during the BAQS-Met IP. 00:00 UTC/8 p.m. LT rawindsonde data from the closest rawinsonde station (DTX) northwest of Detroit, Michigan, were used (see Fig. 2a for location). In cases where the $850 \mathrm{hPa}$ wind was not available at 00:00 UTC, or precipitation was falling at DTX in the hour preceding 00:00 UTC, the 12:00 UTC/8 a.m. local sounding was used.

dence suggests that events at these sites were related to lake breeze passages, whereby air enriched in $\mathrm{O}_{3}$ originating over Lake St. Clair moved inland with the lake breeze (Makar et al., 2010b; Hayden et al., 2011). It is also possible that enhanced local vertical motion associated with the lake-breeze front led to dilution of $\mathrm{NO}_{\mathrm{x}}$ and mixing of $\mathrm{O}_{3}$ from aloft to the surface.

\section{Meteorology and air quality during the intensive period}

During the 21 day IP, synoptic winds from the southwest and west-northwest were most frequent (Fig. 4). Light and moderate synoptic winds were observed with nearly the same frequency, while strong synoptic winds were observed on only two days. Thunderstorms occurred in the study region on five IP days. Lake breezes were observed simultaneously on at least one shore of all three lakes (Huron, Erie and St. Clair) on every IP day (Sills et el., 2011). Lake-breeze front passages were observed in all parts of southwestern Ontario, nearby southeast Michigan and northern Ohio. The median inland penetration distances for the fronts ranged from 45 to $75 \mathrm{~km}$, while the maximum was $215 \mathrm{~km}$ from the Lake Huron shore. On 2 days, at least one station experienced separate lake-breeze front passages originating from all 3 lakes. 


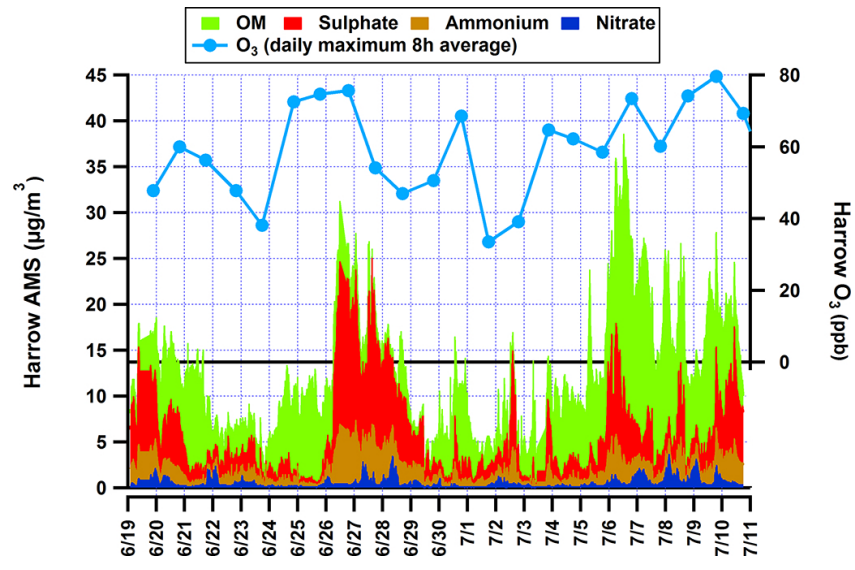

Fig. 5. Variation in $\mathrm{PM}_{1}$ composition $\left(\mu \mathrm{g} \mathrm{m}^{-3}\right)$ and maximum daily $8 \mathrm{~h}$ average ozone (ppb) observed at Harrow, Ontario, during the BAQS-Met intensive period. OM represents organic matter on $\mathrm{PM}_{1}$. There were eight days with daily maximum $8 \mathrm{~h}$ average ozone above the threshold of the Canadawide Standard (65 ppb).

Figure 5 summarizes the air quality conditions during the IP using $\mathrm{O}_{3}$ and $\mathrm{PM}_{1}$ Aerosol Mass Spectrometer (Aerodyne AMS) measurements from Harrow (Slowik et al., 2011). Data from this site shows that there were two periods of elevated $\mathrm{O}_{3}$ and $\mathrm{PM}_{2.5}$ ("episodes"). There were also six "clean days" when $\mathrm{O}_{3}$ and $\mathrm{PM}_{2.5}$ approached continental background levels, with a minimum on 1 July. The first air quality episode started on Sunday, 24 June and ended on 27 June. The $8 \mathrm{~h}$ maximum $\mathrm{O}_{3}$ was above the CWS $(65 \mathrm{ppb})$ for three of these days (25-27 June). Figure 6 shows the Harrow meteorological conditions corresponding to Fig. 5 and includes back-trajectories associated with the two episode periods. The large variations in $\mathrm{O}_{3}$ and $\mathrm{PM}_{2.5}$, from background to concentrations in excess of the CWS, were primarily a result of these meteorological changes and associated local lake-related circulations. This dominance of meteorology on the observed concentrations made any impacts associated with weekday/weekend/holiday variations in emissions difficult to uncover.

The first episode period was associated with an increase in daily maximum temperature and ended with precipitation. The back-trajectories in Fig. 6 show that at the start of the period a northerly flow shifted to bring an air mass from Ohio, which had stagnated over that area allowing Midwestern emissions to build-up before being transported to southwestern Ontario. The southwesterly flow increased in speed as this episode progressed. In addition to the regional-scale transport of $\mathrm{O}_{3}$ and $\mathrm{PM}_{2.5}$, high-resolution model simulations for 27 June (Makar et al., 2010b) showed additional $\mathrm{O}_{3}$ being generated locally in lake-breeze front convergence zones related to fronts from Lakes Erie, Huron and St. Clair.

The AMS measurements in Fig. 5 indicate that the high particle mass from 25-27 June was driven by an increase in ammonium sulfate. Back-trajectories and single particle mass spectrometer data discussed in McGuire et al. (2011) suggest that long-range transport from the lower Midwest and Ohio River Valley contributed significantly during this time with the high sulfate likely due to coal-fired power plant emissions of $\mathrm{SO}_{2}$. Local emissions also led to enhancement in $\mathrm{PM}_{2.5}$ concentrations.

The second IP episode lasted for multiple days (4-10 July), but its characteristics varied throughout its duration. The trajectory plot for the latter part of this period (right side of Fig. 6) shows that when particle concentrations increased on 6 July there was a northwest to north flow crossing the Detroit and Windsor areas. Local emissions thus played a greater role during this part of the period compared to the first episode, but the location of their impact varied depending upon the synoptic wind direction and lake breezes (Levy et al., 2010). This is discussed further below. At the beginning of the second IP episode, $\mathrm{O}_{3}$ increased on 3 July followed by a large rise in sulfate and ammonium on 4 July. Late on the 5th organic matter (OM) became the dominant $\mathrm{PM}_{1}$ constituent, peaking on the 6th and remaining dominant through the 7th, associated with greater impact by nearby Detroit and Windsor. As discussed below, McGuire et al. (2011) also found that more distant biomass burning emissions were brought into the region with the northwest flow, further contributing to the large $\mathrm{OM}$ and $\mathrm{PM}_{1}$ concentrations. On the 8th, sulfate equaled the concentration of OM resulting in another maximum in $\mathrm{PM}_{1}$ mass during the afternoon of the 9th. The trajectories indicated that the US Midwest source region was an important contributor to these high concentrations. The $\mathrm{CWS}_{3}$ also had its maximum on this day $(80 \mathrm{ppb})$. Due to greater transport distances and stronger winds, which serve to homogenize the air mass, these high levels were observed equally across the three supersites, as well as at the other measurement sites in southwestern Ontario.

During the middle of the second episode (6-7 July), $\mathrm{O}_{3}$ concentrations varied considerably between Harrow and Bear Creek. This small-scale spatial variation is an indication that local sources had a considerable influence on concentrations. The lake breeze from Lake Erie, as well as the prevailing synoptic winds, impacted the spatial and temporal heterogeneity in $\mathrm{O}_{3}$ and $\mathrm{PM}_{2.5}$. Levy et al. (2010) showed that emissions in the Detroit-Windsor area contributed significantly to the high $\mathrm{O}_{3}$ at Harrow on the 6th with Lake Erie playing an important role. Under northerly winds the Detroit River and western Lake Erie first played a role early on the day by funnelling and accumulating the emissions and secondary products from the Detroit-Windsor area. Then, lake breezes, which were active and complex on the 6th, brought this polluted air mass inland, as indicated by the high OM concentration during the afternoon, the highest observed during the IP $\left(18 \mu \mathrm{g} \mathrm{m}^{-3}\right)$.

Steady west-southwest winds with temperatures above $30^{\circ} \mathrm{C}$ developed on 8 July. Model simulations for this day (Makar et al., 2010b) showed a similar pattern of local $\mathrm{O}_{3}$ enhancements as on 27 June, indicating that regional transport 


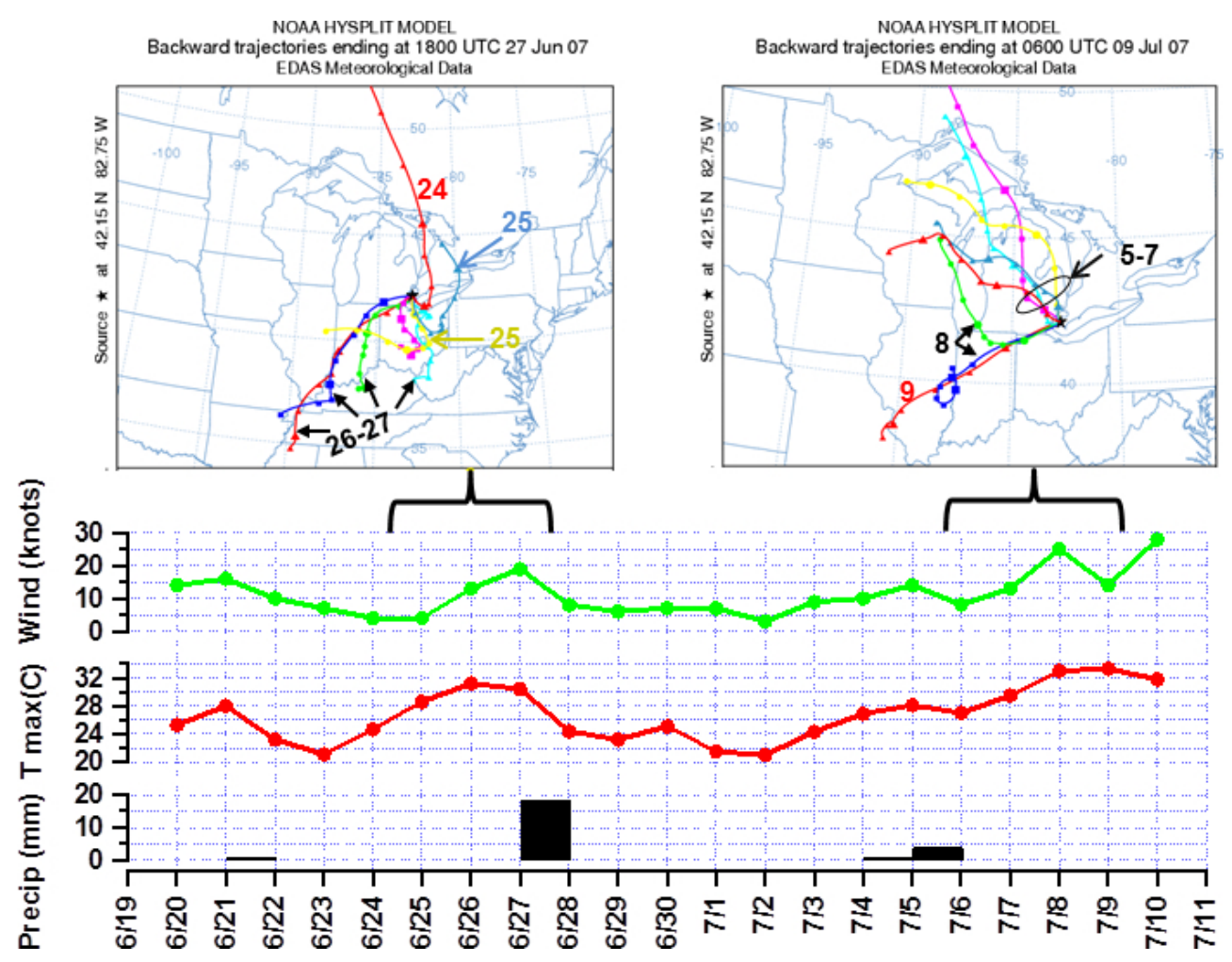

Fig. 6. Time series of mean $850 \mathrm{hPa}$ wind speed, daily maximum temperature and daily precipitation accumulation at Harrow. Three-day back-trajectories arriving every six hours corresponding to the two episode periods are shown in the top two panels. Trajectories are labelled with dates in June (24-27) and July (5-9) of arrival at Harrow.

from the Midwest US was not solely responsible for the high concentrations. For example, model mass tracking applications showed lines of enhanced $\mathrm{O}_{3}$ extending from the northern end of Lake St. Clair all the way to Toronto (eastern edge of domain) related to lake-breeze-induced convergence zones. These narrow zones of enhanced $\mathrm{O}_{3}$ were confirmed using the mesonet $\mathrm{O}_{3}$ observations. The spatial heterogeneity in $\mathrm{O}_{3}$ diminished for the remainder of the IP. Bear Creek experienced a couple of $\mathrm{O}_{3}$ peaks that were not observed at Harrow, likely due to its location downwind of Detroit and local (re-)circulation urban air over Lake St. Clair at this time. The background $\mathrm{O}_{3}$ at most mesonet sites was similar, but daily enhancements at individual sites up to $30 \mathrm{ppb}$ were observed and simulated (Makar et al., 2010b). These events were associated with convergence between the lake-breeze fronts in the region.

\section{Main scientific findings from the BAQS-Met study}

Results in the individual papers of the Special Issue demonstrated that the interaction of Great Lakes-driven meteorology and local sources had a significant influence on $\mathrm{O}_{3}$ and $\mathrm{PM}_{2.5}$ behaviour in the region. Here, we assess whether the study hypotheses are supported by those findings.

\subsection{Hypothesis 1: the relative importance of local emissions is enhanced due to the presence of the Great Lakes}

BAQS-Met measurements and modelling provided clear evidence that the Lakes contribute to enhancement of $\mathrm{O}_{3}$ formation from local emissions. Evidence of increases in secondary aerosols is less clear. However, shifts in the level of oxidation of organic aerosols were observed to accompany lake-influenced $\mathrm{O}_{3}$ changes, and airborne measurements obtained through a lake-breeze circulation detected enhanced secondary PM formation rates relative to regional background formation rates (Hayden et al., 2011). In addition, significant peaks in inorganic secondary species (i.e., sulfate) were observed in locations where the Lakes were influencing local-scale flow patterns and increases in oxygenated organic aerosol mass were observed in urban outflow.

\subsubsection{Processes involved in lake-related local enhancement}

Three processes were identified by which the lakes contribute to the enhancement of local emissions on $\mathrm{O}_{3}$ concentrations. The common feature in each process is the confinement of pollutants within a smaller volume than would otherwise occur. The spatial size of the boundary-layer features associated 
with these processes tend to be relatively small, or confined to narrow elongated lines along frontal convergence zones, with a cross-frontal extent of only a few tens of kilometres. As a result, localized peaks in $\mathrm{O}_{3}$, which can be at least $30 \mathrm{ppb}$ above the regional background, may only be detected by a small number of monitoring sites or could even remain undetected.

The first process is the trapping of $\mathrm{O}_{3}$ or its precursors in a stable and shallow layer over the cooler lake surface, with consequent enhanced secondary pollutant formation over the water compared to terrestrial locations. Associated with this first process is reduced loss of $\mathrm{O}_{3}$ over the lake due to decreased dry deposition and titration with NO. With respect to southern Ontario, there are ample emission sources near Lakes St. Clair, Lake Erie and southern Lake Huron. These pollutants can be brought over the lakes with the synoptic flow or as a direct effect of lake-land breeze circulations. The pollutants remain concentrated near the lake surface contributing to greater local production of $\mathrm{O}_{3}$. This would not occur if the lakes were not present. BAQS-Met model mass tracking calculations (Makar et al., 2010b; Levy et al., 2010) simulate this process, showing intense photochemical $\mathrm{O}_{3}$ production over Lakes Huron and Erie in a layer $\sim 200$ $250 \mathrm{~m}$ deep, and in a $1500 \mathrm{~m}$ deep circulation associated with Lake St. Clair and linked with Detroit's heat island (Makar et al., 2010; Levy et al., 2010).

In situ observations at Harrow, meteorological analyses, modelling and satellite observations indicate that $\mathrm{O}_{3}$ formation over western Lake Erie is controlled by the first process (Levy et al., 2010; Makar et al., 2010b; Halla et al., 2011). For example, satellite observations show higher levels of $\mathrm{NO}_{2}$ over western Lake Erie compared to surrounding areas, particularly for NW flow (Lee et al., 2011). Lake influenced air masses exhibit a range of photochemical ages, but tend to be more aged than air over land. Dramatic air mass age changes were observed at Harrow when influenced by Lake Erie (i.e., Fig. 5: 6-7 July; also Levy et al., 2010). Despite a location only $30 \mathrm{~km}$ from Detroit/Windsor, air mass ages recorded at Harrow ranged from relatively fresh to highly processed, providing evidence that air over Lake Erie undergoes intense photochemical aging. Aircraft measurements also showed that the air over Lake Erie was aged relative to land-influenced air (Hayden et al., 2011).

The second and third processes confine pollutants and precursors to limited areas in the vertical and horizontal dimensions, respectively. The necessary condition for both of these processes is a surface convergence zone near an area of anthropogenic emissions. Lake breezes interacting with each other or with the synoptic flow lead to horizontal convergence. Such conditions are common in the late spring and summer (Sills at al., 2011). The position of the convergence zone or lake breeze front(s) will ultimately determine the extent that the pollutants are transported horizontally and/or vertically while forming a greater amount of $\mathrm{O}_{3}$, and potentially $\mathrm{PM}_{2.5}$, compared to other nearby areas.
The second process is one of vertical recirculation of pollutants under weak synoptic flow. The axis of this motion may occur parallel to the shoreline, with subsidence over the lake, upward motion over the land, and an overall helical motion along the shoreline (Hayden et al., 2011; Makar et al., 2010b). Under weaker synoptic flow, $\mathrm{O}_{3}$ formation is enhanced to the north of the Detroit metropolitan area along the Lake St. Clair shore or along the lake breeze front as it moves inland over Detroit. Enhanced $\mathrm{O}_{3}$ extends to higher vertical levels compared to areas not affected by the lakes, and the region of increased peak $\mathrm{O}_{3}$ production extends to $1000 \mathrm{~m}$ above the surface. Model simulations show that the photochemical production occurs in regions of updraft convergence and enhanced vertical transport. The $\mathrm{O}_{3}$ formed aloft may then be drawn downwards over Lake St. Clair in the return flow associated with the lake breeze circulation, contributing to a "dome" of higher $\mathrm{O}_{3}$ over parts of the lake (see cross section in Figure 19 of Makar et al., 2010b). While a region of enhanced $\mathrm{O}_{3}$ was observed over Lake St. Clair, the full recirculation process was difficult to observe (Hayden at al., 2011), given that return flows counter to greater synoptic flows are more difficult to discern. Hayden et al. (2011) did find evidence of "net" return flow in the lake breeze circulation over Lake St. Clair and presented a vertical cross section (Figure 8 in Hayden et al., 2011) to depict this case. Their analysis also indicated enhanced secondary aerosol formation associated with the circulation at the lake breeze front, thus enhancing the importance of local emissions.

The third process occurs under stronger synoptic flow compared to the second process, with the generation of deeply penetrating lake breeze fronts associated with deformed lake breeze circulations. Meteorological analyses show that these lake breeze frontal zones of convergence over southern Ontario (Sills et al., 2011) are common warmseason features which appear at the same time of day, but with the location and orientation dependent upon the synoptic winds (Makar et al., 2010b). In many cases they occur downwind of the local source areas and can extend tens to hundreds of kilometres downwind of the Lakes. AURAMS simulations suggest that along these zones $\mathrm{O}_{3}$ and/or its precursors tend to be confined, leading to enhanced concentrations. The enhancement region becomes elongated under stronger synoptic winds, resembling "pipelines of $\mathrm{O}_{3}$ " (see Figure 12a; Makar et al., 2010b). A convergence zone related to the lake breezes originating from Lakes St. Clair, Erie and Huron appears to be a regular feature in southwestern Ontario (Figure 17; Makar et al., 2010b), leading to confined horizontal transport, a helical circulation pattern (see Figure 14; Makar et al., 2010b) along the axis of convergence, and enhanced $\mathrm{O}_{3}$ on a $30 \mathrm{~km}$-wide line extending up to $200 \mathrm{~km}$ downwind from Detroit-Windsor. 


\subsubsection{Local enhancement or modification of aerosols due to the Lakes}

The process of lake-enhanced secondary aerosol formation has not been explored in the past. This was mainly due to lack of time-resolved PM measurement methods. An extensive suite of aerosol measurements were obtained during BAQS-Met (Slowik et al., 2011; Stroud et al., 2011; Jeong et al., 2010; McGuire et al., 2011). Hayden et al. (2011) focused on the question of the impact of the lake circulations on aerosol formation rates compared to adjacent land areas, specifically the formation rates of secondary sulfate and organic aerosol relative to $\mathrm{SO}_{2}$ and $\mathrm{CO}$, respectively. Estimates of the formation rates of these aerosol species in the convergence zones were greater than what was observed in the surrounding regional background. The aerosol characteristic patterns inferred from the data were also found to be linked to helical circulations, which enhanced local processing of emissions not far downwind Detroit-Windsor.

\subsubsection{Evidence of enhanced local source contribution to secondary pollutants}

The unprecedented level of temporal and spatial observations during the study showed a large degree of spatial heterogeneity associated with local sources and lake-induced meteorology. This suggests the importance of local sources to observed air pollution (Makar et al., 2010a, b; Stroud et al., 2011, 2012; Ellis et al., 2011; Markovic et al., 2011; Sills et al., 2011). Model-predicted surface $\mathrm{O}_{3}$ showed a high degree of spatial variability, both as instantaneous maps and as hour-of-day averages over multiple days. This degree of variability is consistent with the observations discussed above and by Levy et al. (2011). Model results (Makar et al., 2010) showed that the study mean afternoon $\mathrm{O}_{3}$ was enhanced by $10 \mathrm{ppb}$ within $50 \mathrm{~km}$ of Lake Erie. Enhancements of $30 \mathrm{ppb}$ occurred over shorter distances, downwind of intense source areas within lake-breeze-induced air mass convergence zones. Such variability was also predicted over the lakes, where pockets of higher $\mathrm{O}_{3}$ and precursors remained intact due to suppressed dispersion. This spatial heterogeneity in $\mathrm{O}_{3}$ provides good evidence that local emissions and secondary formation processes have a significant impact in the BAQS-Met study region. Ozone transported into the region is expected to be more dispersed upon reaching the region, resulting in more uniform levels and similar temporal changes across multiple stations.

The BAQS-Met study contributed new time-resolved aerosol speciation data, which allowed an assessment of spatial and temporal heterogeneity of aerosols. Aircraft AMS data examined in Hayden et al. (2011) demonstrated considerable small-scale heterogeneity in secondary aerosol constituents, particularly for sulfate. The differences in aerosol composition between Harrow and Bear Creek presented in Slowik et al. (2011) also revealed that there can be consid- erable small-scale variability. Their work provided new evidence of organic aerosol formation downwind of the DetroitWindsor area, as well as in the regional background air. Furthermore, they showed that anthropogenic aerosols can interact with biogenic VOC precursors to form secondary organic aerosols (SOA). Rapid hourly variation in observed organic aerosol formation presented in Stroud et al. (2011) showed the small spatial extent and local episodic nature of organic aerosol events in the region, as well as the need for highresolution modelling for its accurate simulation. Based upon the BAQS-Met period, Li et al. (2011) showed that there is also the potential for VOCs emitted by motor vehicles to form SOA through reaction with aerosol sulfate.

Chan et al. (2011) observed rapid changes in the specific absorption cross section (SAC) of black carbon (BC), which were argued to be due to changes in coating thickness relative to the amount of $\mathrm{BC}$. This variation suggests significant temporal and spatial heterogeneity in secondary aerosol due to the formation of new particle mass within the study area. Large changes in the SAC were observed from CRUISER when in the vicinity of a lake-breeze front (Chan et al., 2011), coincident with rapid meteorological changes, indicating the impact of local circulation and sources. Specifically, within a short time window, the BC sources varied from local, fresh combustion, to aged air from aloft and to moderately aged air from over Lake Erie. Hayden et al. (2011) were able to demonstrate one relatively clear case in which lake-breeze circulations had an important influence on the formation of sulfate and SOA. They observed enhancements, relative to regional background, of $\mathrm{SO}_{4} /\left(\mathrm{SO}_{2}+\mathrm{SO}_{4}\right)$ and $\mathrm{OM} / \triangle \mathrm{CO}$ (ratio of total particle organic matter and background-adjusted $\mathrm{CO}$ ) along the south shore of Lake St. Clair at different points within the lake-breeze circulation. Cloud processing and/or enhanced oxidant availability due to pollutant confinement associated with the circulation may have played a role in enhancing secondary particle formation. These individual case studies from BAQS-Met (Chan et al., 2011; Hayden et al., 2011) suggest enhancement of particle formation near the lakes based on observational evidence. The local meteorological features thus give rise to conditions of enhanced secondary particle formation. The extent to which this formation is associated with more-aged particles in regional background air versus local processing is more difficult to discern from the measurement record. Unpublished model process analyses from BAQS-Met do suggest that clouds forming in the lake-breeze convergence zones, along with the enhanced aerosol precursor concentrations of $\mathrm{SO}_{2}$, may be regions of rapid aerosol sulfate formation.

A high degree of spatial variability was expected for primary gaseous pollutants such as $\mathrm{SO}_{2}, \mathrm{NO}_{\mathrm{x}}$ and $\mathrm{CO}$. The exact origin of primary pollutants was sometimes difficult to discern due to rapidly changing meteorological conditions in the local environment. At Ridgetown, which is farther from the main sources, Halla et al. (2011) used surface measurements of $\mathrm{NO}_{2}$ and $\mathrm{SO}_{2}$ along with aerosol optical depths 
(AOD) and $\mathrm{NO}_{2}$ vertical column densities (VCD) derived from MAX-DOAS to identify the passage of an elevated plume associated with several combustion sources in the Sarnia-Lambton region. This period of elevated concentration at Ridgetown (12:00-13:00 EDT on 30 June) occurred in conjunction with some changes in the passage meteorological conditions similar to a lake-breeze front, and demonstrated the complex behaviour of local primary emissions within the circulation through: (1) increases in $\mathrm{NO}_{2}$ aloft prior to that at the surface, indicating a complex 3-D structure; (2) the increase in surface $\mathrm{NO}_{2}$ and $\mathrm{SO}_{2}$, indicating fumigation; (3) a sharp increase in $\mathrm{NO}_{2}$ at the surface accompanied by increased VCD of $\mathrm{NO}_{2}$ indicating accumulation and confinement at the front as well as a significant vertical extent to the phenomena. The interaction of lake-related circulation patterns with large point source emissions as detected by Halla et al. (2011) can lead to complex small-scale features that are not straightforward to diagnose in terms of the sources responsible. The availability of MAX-DOAS measurements during BAQS-Met added considerable insight and demonstrated that gaining an understanding of such events is limited with only ground-level measurements.

Collectively, the results discussed above indicate that elevated $\mathrm{O}_{3}$ and $\mathrm{PM}_{2.5}$ observed in the region are due to formation from anthropogenic emissions in the immediate vicinity of the lakes. Typical $\mathrm{O}_{3}$ enhancements seen above regional levels are as high as $\sim 30 \mathrm{ppb}$ and, in addition to the local emissions, the complex transport patterns induced by the lakes dictate where and when these peak concentrations occur. Some observations also indicate that particle levels are enhanced when local $\mathrm{O}_{3}$ peaks occur and that there is local secondary aerosol formation. Changes in $\mathrm{O}_{3}$ and aerosols in connection with the lake-breeze circulation pattern and a greater frequency of high $\mathrm{O}_{3}$ concentration events closer to the lakes during the day, and at night over Lake Erie, further highlight the role of the Great Lakes in local secondary pollutant formation.

\subsection{Hypothesis 2: vertical motions induced by lake-breeze circulations and other surface-related features play a significant role in the transport and chemistry of pollutants and the initiation of thunderstorms in the Great Lakes area}

Understanding vertical motion in the region was hypothesized to be critical in gaining a better understanding of pollutant movement. The classic circulation pattern related to differential daytime heating of the land and lake surfaces was discussed by Sills et al. (2011). A schematic diagram therein illustrates conceptually the air movements and modified boundary layers associated with lake-breeze circulations. The ideal "classic" lake-breeze circulation occurs with clear skies and weak synoptic winds. Net upward transport of pollutants is expected along the advancing lake-breeze front over land while subsidence is expected over the lake.
Lake-breeze circulations become more deformed as the synoptic flow increases, displacing the circulations downwind and causing significant changes to lake-breeze fronts (Sills et al., 2011). Interaction between multiple lake-breeze circulations or a lake-breeze circulation and the circulation associated with an urban heat island can contribute to the complexity, all leading to significant spatial variability in the magnitude of vertical motions over land and enhanced potential for convective precipitation.

Model runs and diagnostic analyses in several papers revealed that vertical transport of air pollutants played a significant role in creating spatially heterogeneous concentration patterns, with key features including: (1) heat-island urban updraft circulation over Detroit (Flagg and Taylor, 2011) linked with downwind lake-induced subsidence (Lake St. Clair); (2) helical recirculation, both along shorelines (Lake St. Clair) and along the axis of lake-breeze front convergence zones between the Lakes; (3) convective activity triggered along the lake-breeze front convergence zones, further enhancing upward motion and downwind transport. Comparisons between aircraft measurements of instantaneous vertical velocity at lake-breeze fronts and $2.5 \mathrm{~km}$ grid spacing model simulations, which are ongoing, suggest that the model predictions at that resolution tend to be much lower in magnitude than observations. This difference in magnitude may have significant implications for the simulation of both chemical transport and thunderstorm initiation.

\subsubsection{Observations of pollutant transport related to vertical motion}

Vertical motions were examined in conjunction with pollutant observations by Hayden et al. (2011). They examined a case study (25 June 2007) centred on aircraft flights from Lake Erie to north of Lake St. Clair which involved multiple heights and the crossing of two well-defined lake-breeze fronts. To summarize understanding, they proposed a conceptual model to explain the observed complex 3-D circulation patterns associated with the intersection of these two lake-breeze circulations (Lake Erie and St. Clair). Vertical turbulence was greatly suppressed over both lakes, while being active over the landmasses in the convective boundary layer (CBL). A classic 3-D lake breeze re-circulation pattern was only partially detected on the Lake Erie lake breeze circulation due to the influence of the synoptic winds, but enhancements in upward and downward motion at the Lake St. Clair front on land and lake sides of the front were detected. The high-resolution GEM simulated this behaviour reasonably well (Hayden et al., 2011) and model trajectories revealed air parcel movements consistent with re-circulation, including low-level onshore flow, rising air inland, an elevated return flow and a helical recirculation pattern along the south shore of Lake St. Clair. Enhanced oxygenated organic aerosol and sulfate formation rates were observed in this recirculation pattern relative to non-lake influenced rates. 
The airborne measurements during 25 July case showed marked changes in concentrations over short distances. These included differences in the maximum height of polluted air; with it being higher at the Lake St. Clair front, and elevated layers of polluted air over Lake St. Clair. Concentration gradients were noted at the frontal boundaries denoting differences between the land-based convective boundary layer and the lake-modified air. In particular, the circulation pattern at the Lake St. Clair front led to a $\sim 10 \mathrm{~km}$ wide region of enhanced $\mathrm{CO}$ and $\mathrm{SO}_{2}$ concentrations in the lake air near the frontal boundary. Lake St. Clair subsidence and onshore flow, shown by cross section in Figure 8 of Hayden et al. (2011) were hypothesized to confine pollutants in this area.

Overall, the case study presented by Hayden et al. (2011) highlighted the complexity of the 3-D wind patterns induced by the lakes, while also showing that pollutant concentrations varied over short horizontal and vertical distances under the influence of these wind patterns. This complex flow made assigning the various peaks in primary and secondary pollutants to specific source areas exceptionally difficult. As an example, while the synoptic wind flow during their case study would suggest that emissions from Detroit-Windsor and western Lake Erie would move northeast across Lake St. Clair, the diagnosed trajectory from high-resolution modelling suggested a much more complex situation. Emissions from these regions travelled east into the CBL in the morning between Lake Erie and Lake St. Clair. From here the air was mixed vertically, moved off-shore aloft, subsided over Lake St. Clair and was caught in the lake breeze recirculation, before eventually leaving the area aloft in the synoptic flow to the north. The significance of this circuitous transport path is that pollutants arriving north of Lake St. Clair were more-aged than they would be without the lake influences described here. The high $\mathrm{O}_{3}$ north of Lake St. Clair observed during this case $(\sim 100 \mathrm{ppb})$ was likely influenced by this extended air mass history.

Other fine-scale phenomena related to vertical motions were uncovered through ground-based measurements. Levy et al. (2010) reported on multi-site high-frequency ( $\sim 10 \mathrm{~min}) \mathrm{O}_{3}$ oscillations on the order of $20 \mathrm{ppb}$ after sunset. It was not possible to explain their cause, but vertical motion induced by a low-level jet was one possible mechanism. Levy et al. (2010) also demonstrated how the daily break-up of the nocturnal boundary layer at around 10:30 EDT led to a brief $\left(\sim 1 \mathrm{~h}\right.$ ) homogenization of surface $\mathrm{O}_{3}$ between locations over land (urban and rural) and over water. Chan et al. (2011) presented two case studies of enhanced black carbon (BC) light absorption showing that aged $\mathrm{BC}$ particles from aloft were mixed to the surface. The hallmark for both cases was increased surface wind speed and/or gusts. One of those cases was directly related to vertical motions associated with the Lake Erie lake breeze front. Periods of limited vertical mixing leading to vertical stratification of pollutant layers were also observed. Most notably, under northerly flow Halla et al. (2011) detected elevated layer(s) of $\mathrm{NO}_{2}$ over Ridgetown with the likely source area being $\sim 50 \mathrm{~km}$ upwind; this suggests a period of relatively widespread stability in the lower troposphere affecting the domain.

\subsubsection{Model applications linking vertical motions and pollutant patterns}

Coupling the analysis of the daily frontal movements with observed chemical variations provided insight regarding air mass changes over short space-time scales. This enabled systematic evaluation of the high-resolution meteorological model's ability to reproduce local circulation patterns (Sills et al., 2011). The model predicted an area of frequent surface-level convergence northeast of Detroit, with consequent upward motion, enhanced $\mathrm{O}_{3}$ formation and peak $\mathrm{O}_{3}$ occurring $\sim 1000 \mathrm{~m}$ above the surface (Makar et al., 2010b; Levy et al., 2010). This pattern suggests that convergence areas and focused vertical transport serve to confine local precursors and $\mathrm{O}_{3}$, enhancing photochemistry as the air rises. Aloft, this pollutant-rich air moves over Lake St. Clair leading to a $1500 \mathrm{~m}$ "dome" of higher $\mathrm{O}_{3}$ over the lake (Makar et al., 2010b), consistent with the aircraft observations (Hayden et al., 2011). High photochemical production over the larger lakes in the study area appears to be limited to a layer 200-250 m deep over Lakes Huron and Erie (Levy et al., 2010; Makar et al., 2010b). However, AURAMS results indicate that over southern Lake Erie near Cleveland, as well as inland, there are zones of strong vertical updrafts reaching $1500 \mathrm{~m}$ (Levy et al., 2010). This area of high $\mathrm{O}_{3}$ appears to be related to a lake breeze circulation on the south shore of Lake Erie.

Flagg and Taylor (2011) explored meteorology related to the urban heat island in the Windsor-Detroit area. Through a variety of sensitivity analyses with the Weather Research and Forecasting (WRF) model, they found that changes in the scale of the surface classification had non-negligible impacts on predictions of the onset of nocturnal static stability, lake breeze front penetration and boundary-layer depth. Implicit in these findings are impacts on the 3-D distribution of vertical motions in the area. Their results make it clear that limitations in the meteorological modelling must be well understood before it is applied for high-resolution analysis of air pollutants.

\subsection{Hypothesis 3: the accuracy of air quality and weather forecasting for southern Ontario is significantly impacted by how well the models and the weather data assimilation system treat these processes over the Great Lakes}

Understanding the capabilities of Environment Canada's operational and research-oriented meteorological model, GEM, was one of the main goals of the analyses presented by Sills et al. (2011). Their comparison of GEM high-resolution 
$(2.5 \mathrm{~km})$ runs with the mesonet data demonstrated that the model could accurately predict lake breeze occurrence and degree of deformation under a variety of synoptic wind regimes. However, some cases were noted with substantial differences between observed and simulated timing and location of lake breeze fronts, and with the timing of the initiation of deep moist convection.

In a closer look at the model's performance around a lake breeze front, Hayden et al. (2011) concluded that AURAMS and hence GEM reproduced the observed chemical features during the day's first flight on the morning of 25 June reasonably well, but was not able to match the observed chemical and meteorological conditions four hours later during the second flight, when the lake breeze fronts from Lakes Erie and St. Clair had merged. In between these flight times a new data assimilation cycle was initiated by the meteorological modelling system and this may have been responsible for its poorer performance. The analysis of Hayden et al. (2011) therefore only focused on the first flight, and this example serves to further highlight the critical importance of accurate meteorological modelling in the region to subsequent air quality model accuracy.

\subsubsection{The importance of model resolution}

The results above summarize how meteorology induced by the Great Lakes impacts air quality. Complex, local-scale 3D pollutant transport patterns and secondary formation processes led to a high degree of spatial and temporal heterogeneity in concentrations. High-resolution models helped support the analyses presented above and can be expected to be required for accurate air quality forecasting in the Great Lakes region. Clearly, for a model to be useful in such a region, the resolution must be adequate to resolve the lake breeze circulations along with the strength of updrafts at the lake breeze front (Sills et al., 2011). Short time steps $(\sim 1-$ $2 \mathrm{~min}$ ) are essential in both the meteorological and air-quality models in order to simulate rapid changes in flow.

Stroud et al. (2011) considered the impact of horizontal resolution on model performance for organic aerosol (OA) predictions and SOA formation. They found that maximum SOA concentrations depended strongly on the model's horizontal resolution. Histograms of model OA loading at the supersites revealed that significant improvements occurred with increasing resolution. The highest resolution model simulations $(2.5 \mathrm{~km})$ were able to capture short-duration "spikes" in the spatial distribution of aerosol precursors that the lower resolution simulations could not, allowing for local enhancements in the non-linear production of condensable organic material. The domain total SOA did not change significantly with model resolution. However, the increase in resolution sharpened the gradients of OA, allowing for local increases of SOA mass similar to the observations due to better representation of several processes such as the relationship between SOA production rate and existing OA mass. Their re- sults are important in evaluating the different parameterizations used in simulating OA. Negative biases in urban organic aerosol predictions may be the result of the model resolution, as opposed to the SOA estimation methodology. This finding should be evaluated further using long-term observations of $\mathrm{OA}$ and longer duration high-resolution model simulations.

Makar et al. (2010b) showed that the highest resolution nest of the air-quality model ( $2.5 \mathrm{~km}$ horizontal resolution) provided the best comparison with surface $\mathrm{O}_{3}$ observations. This analysis was complicated, however, by smaller numbers of observation stations being available for comparison to model output at each successively higher resolution.

\subsubsection{The need for improvements in the model emissions inventory}

Accurate emission inventories are well-recognized as one of the most important components of air quality modelling. Despite continued improvement, many limitations remain (cf., NARSTO, 2005), such as outdated emission factors and activity data and inappropriate spatial surrogates for geolocating area source emissions. Comparisons between US and Canadian emissions at high resolution, done as part of the BAQS-Met modelling exercise, were an invaluable tool for identifying problems and improving the emissions inventories. Discontinuities in emissions across political boundaries may reflect real differences in emitting activities, or differences in the emission estimation methodology. For example, examination of the BAQS-Met emissions input showed a sharp international discontinuity for marine vessel emissions on the Lakes. The methodology followed for spatially allocating the Canadian inventory was to place all the estimated emissions, commercial and recreational, along the major shipping lanes. In contrast, US emissions methodology placed commercial shipping emissions along shipping lanes, while emissions associated with recreational boating were distributed over the Lake surfaces, based upon countylevel statistics. This led to differences in predicted $\mathrm{O}_{3}$ across the international border over Lake Erie, demonstrating that variation in spatial allocation methodologies require further attention in order to improve modelling results in the region.

Similar differences between Canadian and US emissions for on-road mobile sources were found for the highresolution BAQS-Met modelling domain. At the time of the simulations, only one spatial surrogate was available for allocating Canadian mobile emissions, while 6 surrogates were available in the US. Improved spatial surrogates for Canadian mobile emissions have been created following this comparison, using newly collected geo-referencing data, and are now in use at Environment Canada (Zhang et al., 2012).

Model predictions of primary organic aerosol (POA) were evaluated by Stroud et al. (2012). Model bias in POA was assessed using Windsor observations from CRUISER and supersite measurements at Harrow and Bear Creek (i.e., urban and rural areas). Overpredictions were largest at the urban 
site on calm nights and were attributed to underestimation of vertical mixing, underrepresentation of tailpipe PM emissions along urban roads and highways, and a tendency to allocate area POA sources such as cooking and dust emissions to urban locations. The model bias in POA reduced as the magnitude of diesel emissions increased suggesting an underrepresentation of diesel sources. They concluded that uncertainties in several large POA emission sources, in particular food cooking, fugitive dust, waste disposal burning, and on-road traffic sources need to be reduced in order to improve model predictions and recommended extra focus on improving spatial surrogates and temporal profiles for these sources.

Reliable estimation of biogenic emissions is also critical to air quality model predictions in the region, given that measurement and modelling of VOCs and aerosols indicate that biogenic emissions are a significant contributor to SOA. Positive Matrix Factorization (PMF) analysis of aerosols measured by AMS at both Bear Creek and Harrow identified a PMF factor related to isoprene or isoprene product uptake on sulfate particles, which accounted for $2-4 \mu \mathrm{g} \mathrm{m}^{-3}$ of OA mass during several days of warm weather (Slowik et al., 2011). These PMF results along with concurrent VOC measurements by a Proton Transfer Reaction Mass Spectrometer were also used to estimate the extent to which different VOC precursors contributed to SOA formation (Sjostedt et al., 2011). The analysis suggested that the contribution of biogenic VOC to local SOA formation was at least an order of magnitude greater than anthropogenic aromatic compounds. Indeed biogenic emissions have previously been shown to form a considerable amount of SOA in southern Ontario (Slowik et al., 2010).

\subsubsection{Secondary organic aerosol formation in the urban plume}

Slowik et al. (2011) estimated substantial SOA production rates in air masses arriving at Harrow from Windsor/Detroit. They examined the ratio of SOA to background corrected $\mathrm{CO}(\mathrm{SOA} / \triangle \mathrm{CO})$ in comparison to air mass photochemical age, indicated by the concurrent $\mathrm{NO}_{\mathrm{x}} / \mathrm{NO}_{\mathrm{y}}$ ratio. From this they estimated the SOA formation rate in such plumes to be $\sim 10.1 \mu \mathrm{g} \mathrm{m}^{-3} \mathrm{ppmv}_{\mathrm{CO}}^{-1} \mathrm{~h}^{-1}$. This rate is consistent with that observed in the vicinity of Mexico City and exceeded the formation rates determined at locations further downwind of Mexico City (Slowik et al., 2011). They also estimated a $\Delta \mathrm{SOA} / \triangle \mathrm{CO}$ ratio of about $100 \mu \mathrm{g} \mathrm{m}^{-3} \mathrm{ppmv}_{\mathrm{CO}}^{-1}$. This formation rate is consistent with that summarized over multiple studies in aged urban air masses (De Gouw and Jimenez, 2009), clearly demonstrating that anthropogenic VOCs are an important local precursor to $\mathrm{PM}_{2.5}$ in southwestern Ontario.

Slowik et al. (2011) also observed SOA production in regional background air transported from the south that moved into southwestern Ontario. The rate of SOA production under these conditions was slower than in the air masses originating from the Windsor/Detroit area, but considerably higher than when the origin of the regional background air was from the northwest. It is likely that under the northwest flow conditions, the air mass had already experienced significant photochemical aging. Biogenic precursor emissions may also contribute to local SOA formation, yet this was not observed by Slowik et al. (2011), likely due to the low incidence rates of northwest flow.

The aircraft measurements were also assessed for SOA production with a focus on evaluating the potential for lake breeze circulations to enhance production (Hayden et al., 2011). Measurements of oxygenated organic aerosol (OOA) from PMF analysis, relative to $\mathrm{CO}$ within different air masses were compared not far downwind of Detroit near the Lake St. Clair shoreline. Formation rates in the range of 12 $19 \mu \mathrm{g} \mathrm{m}^{-3} \mathrm{ppmv}_{\mathrm{CO}}^{-1} \mathrm{~h}^{-1}$ were observed, far above the regional background rate, and greater than the rate observed on the ground in the urban plume (Slowik et al., 2011). This suggests an enhanced lake breeze circulation effect on SOA formation. The higher end of the range determined by Hayden et al. (2011) provides some evidence of rapid chemical processing in clouds associated with the lake breeze circulation.

\subsubsection{Evaluating the model capability to simulate $\mathrm{O}_{3}$, particle formation and composition}

Beyond the main study focus of the impacts of the Great Lakes, the diverse measurements led to a number of other improvements to the air quality model. Initial North American domain simulated surface $\mathrm{O}_{3}$ was biased +15 ppb compared to observations. Vertical $\mathrm{O}_{3}$ profiles at Harrow (He et al., 2011) showed that the model bias was even greater in the upper troposphere. Makar et al. (2010a) used ozonesonde data to evaluate the model's prediction of the $\mathrm{O}_{3}$ vertical column, noting that middle tropospheric concentrations had large positive biases. These biases were greatly reduced through a methodology that varied the vertical distribution of climatological $\mathrm{O}_{3}$ boundary conditions in response to modelpredicted tropopause height. The new methodology reduced the mean $\mathrm{O}_{3}$ bias to $+8.6 \mathrm{ppb}$ and also improved the column predictions.

Makar et al. (2010b) evaluated AURAM's $\mathrm{O}_{3}$ performance at multiple resolutions. This revealed that the model simulates the general features determined by diurnal cycles, synoptic-scale changes in levels and hence broad patterns in $\mathrm{O}_{3}$ concentrations, both horizontally and vertically. At times the high-resolution $(2.5 \mathrm{~km})$ AURAMS performed well, discerning small-scale phenomena observed from the aircraft and CRUISER. The correlation coefficient $(R)$ between the model and airborne observations was $>0.5$ for half of the flights $(8 / 16)$ and ranged from $-0.46<R<0.65$. Poor (near zero) correlations resulted for two flights while one flight had a large negative correlation. These statistics reveal considerable uncertainty in how well AURAMS predicts $\mathrm{O}_{3}$ aloft 
at any given time and place. They do not necessarily imply that AURAMS is incorrectly simulating the chemical processes, since predicted locations of $\mathrm{O}_{3}$ deviations are dependent upon the accuracy of the simulated meteorology. The incorrect placement of a lake breeze front by $10 \mathrm{~km}$ could result in an anti-correlation between modelled and observed $\mathrm{O}_{3}$ time series aloft, for example. The BAQS-Met region contains complex meteorological conditions for model evaluation with small-scale transitory $\mathrm{O}_{3}$ features.

Estimates of mean bias are perhaps more informative of model capability in simulating chemical processes aloft. Overall, AURAMS high-resolution $\mathrm{O}_{3}$ predictions were biased low; on the order of -4 to $-9 \mathrm{ppb}$ at the surface, increasing to $-10 \mathrm{ppb}$ along aircraft flight paths. At roadway surface locations (CRUISER driving routes), the bias was found to be worse $(-23 \mathrm{ppb})$. Model predicted $\mathrm{NO}_{2}$ along CRUISER's route was often over a factor of two higher than observed, suggesting excessive $\mathrm{NO}$ titration of $\mathrm{O}_{3}$ in the model in roadway settings. This may be the result of insufficient vertical mixing in the near-surface environment, resulting in $\mathrm{NO}_{\mathrm{x}}$ overpredictions near the surface and insufficient $\mathrm{NO}_{\mathrm{x}}$ aloft. More recent work (Gordon et al., 2012) has examined the possibility that the passage of moving vehicles may influence near-surface turbulent mixing.

Makar et al. (2010b) also used the high-resolution version of AURAMS to assess $\mathrm{O}_{3}$ production sensitivity to its chemical precursors, via perturbing the $\mathrm{O}_{3}$ precursors on hourly intervals to construct local derivatives of changes in $\mathrm{O}_{3}$ with respect to those precursors. They found that instantaneous $\mathrm{O}_{3}$ production $(<5 \mathrm{~min})$ increased with increasing VOC levels in much of southwestern Ontario, while $\mathrm{O}_{3}$ decreased with increasing $\mathrm{NO}_{\mathrm{x}}$; i.e., a VOC-limited regime in that part of the region. Their model study found that $\mathrm{O}_{3}$ formation was very sensitive to the oxidation of aromatics including the aromatic oxidation pathways used in the model's chemical mechanism, as reported for similar evaluations in other regions (Jiang et al., 1997b). The source of aromatic emissions is largely from the mobile sector. Urban $\mathrm{O}_{3}$ in the region was also found to be sensitive to the concentration of anthropogenic $\mathrm{C}_{3}+$ alkenes and isoprene (largely biogenic). The high sensitivity to oxidation products of primary aromatics suggests that the details of the reaction pathways for these species have greater impact than the initial aromatic oxidation. Ultimately, this implies that the net reactivity of aromatics may be the dominant factor in $\mathrm{O}_{3}$ production in this region. This could be confirmed through targeted emissions scenario simulations for specific VOCs in the region. In contrast to the instantaneous $\mathrm{O}_{3}$ sensitivity to VOC's, Nuaaman et al. (2008) found that the daily maximum $\mathrm{O}_{3}$ was $\mathrm{NO}_{\mathrm{x}}$ limited on 8 of 11 days at Ridgetown during the study, including the days of highest $\mathrm{O}_{3}$, using measurements of $\mathrm{HCHO}$ and $\mathrm{NO}_{\mathrm{y}}$ and a Sillman indicator of $\mathrm{HCHO} / \mathrm{NO}_{\mathrm{y}}>0.28$ for afternoon samples (Sillman, 1995).

The AURAMS model was evaluated for its ability to predict inorganic $\mathrm{PM}_{1}$ constituents, specifically, particle nitrate
$<1 \mu \mathrm{m}$ (Markovic et al., 2011). A comparison between the aircraft and the AURAMS predicted particle nitrate showed that model had a mean bias of $-0.23 \mu \mathrm{g} \mathrm{m}^{-3}$. The agreement was better at the Harrow ground site with a model bias of $+0.08 \mu \mathrm{g} \mathrm{m}^{-3}$. However, the model overestimated peak nitrate, and underestimated background levels. Markovic et al. (2011) conducted sensitivity studies by mapping both observations and model results as a function of temperature and free ammonia $\left(\mathrm{NH}_{\mathrm{x}}=\mathrm{NH}_{3}(\mathrm{~g})+\mathrm{NH}_{4}^{+}(\mathrm{p})-2 \mathrm{SO}_{4}^{2+}(\mathrm{p})\right)$. They demonstrated that biases in particle nitrate predictions were due to errors in the predicted relative humidity, temperature and $\mathrm{NH}_{\mathrm{x}}$.

Ellis et al. (2011) also conducted a detailed study of inorganic particle chemistry using high time resolution $\mathrm{NH}_{3}$ measurements at Harrow. Comparison of measured and modelled average diurnal profiles of $\mathrm{NH}_{\mathrm{x}}$ showed a regular pattern in which model values peaked at 06:00 LT, while observations peaked later, at 11:00. The observed $\mathrm{NH}_{\mathrm{x}}$ maximum was $1.5 \mu \mathrm{g} \mathrm{m}^{-3}$ higher than the model, and the observed range of variability in the gas fraction $\left(\mathrm{NH}_{3} / \mathrm{NH}_{\mathrm{x}}\right)$ was smaller than that predicted by the model. The observed gas fraction also correlated with sulfate levels even as the latter became relatively high. This behaviour is strong evidence of bi-directional fluxes of $\mathrm{NH}_{3}$, wherein surface reservoirs release $\mathrm{NH}_{3}$ in response to changing atmospheric conditions (e.g., increased uptake to PM). The model, lacking this process, was not able to reproduce this behavior, with its gas fraction decreasing much more rapidly with increasing sulfate. Initial tests of a simple bi-directional flux parameterization in which a fixed compensation point of $\mathrm{NH}_{\mathrm{x}}$ was used to drive the flux direction improved the gas-fraction relative to observations suggesting that a bi-directional flux algorithm should be considered in the model.

The work of Ellis et al. (2011) and Markovic et al. (2011) illustrates the importance of increasing accuracy in both emissions $\left(\mathrm{NH}_{3}\right)$ and meteorology in the model. The aerosol measurements also reveal the challenge for the model to correctly predict $\mathrm{PM}_{2.5}$ and its composition. This is evident in the work by McGuire et al. (2011), in which 33 common particle types were identified using single particle mass spectrometry (SPMS). Although similarities were observed among these unique types leading to 7 families of particles, there were distinct differences among all 33 in their composition, origin, and sizes. McGuire's work also highlighted the extent of external vs. internal mixing, implying differing degrees of atmospheric processing. Their application of PMF to the time series of the 33 particle types indicated that several types had a tendency to occur concurrently at Harrow. This implies that the sources of some particles were relatively close to Harrow, in that there was insufficient travel time for coagulation and other aerosol processing mechanisms, which operate on timescales of tens of hours to days, to allow the particle types to become internally mixed. Clearly, the complexity revealed by SPMS data is beyond what current models can resolve. Consequently, approaches to determine if the 
bulk features that the model does predict are consistent with what is revealed by the single particle work need to be developed. However, even if such consistency can be shown for the bulk compositional features, there remains a need to predict the mixing state correctly for simulations of regionalscale variations in BC light absorption. Chan et al. (2011) provided several examples in the BAQS-Met region showing that knowledge of bulk particle composition relative to $\mathrm{BC}$ was insufficient to estimate light absorption showing that mixing state plays a significant role in the specific absorption cross section (SAC). In cases where other particle species (e.g., sulfate, organic matter) were high and not coating the BC (i.e., not internally mixed), the SAC was not affected. Nucleation and growth events also contribute additional particles to the air mass and were shown by Jeong et al. (2010) to be relatively common over large regions of southern Ontario. These processes also lead to external mixtures, and hence would have minimal impact on the light absorption properties of the BC.

\section{Conclusions}

This overview paper synthesizes results from papers published in the BAQS-Met Special Issue of Atmospheric Chemistry and Physics in order to draw broader conclusions about the effect of lake-induced meteorology on air quality in the region of southwestern Ontario. We conclude that the presence of the Great Lakes indeed causes an enhancement in the impact of local air pollutant emissions on $\mathrm{O}_{3}$ and $\mathrm{PM}_{2.5}$ levels over southwestern Ontario. The implication of this result is that while regional air pollutants entering southwestern Ontario are often elevated due to long-range transport, strategies to reduce the magnitude and frequency of secondary pollution events can also benefit from controlling local sources. This includes activities within the large urban areas of Detroit and Windsor and industrial point sources in both countries from western Lake Erie to the St. Clair River. Lake breezes influence the movement of pollutants from these source areas almost daily during the summer. The frontal zones related to these mesoscale meteorological features are found to move inland over considerable distances while interacting with the prevailing synoptic winds, with fronts from other lakes, and with local urban heat island circulations. The horizontal and vertical motions at the fronts lead to local re-circulation of primary and secondary pollutants. In addition, these motions result in the pooling of pollutants over the Lakes at night, which contributes to local $\mathrm{O}_{3}$ and secondary $\mathrm{PM}_{2.5}$ maxima in narrow convergence zones $(\sim 10 \mathrm{~km})$ that can extend for more than $200 \mathrm{~km}$ where local maxima in $\mathrm{O}_{3}$ and secondary $\mathrm{PM}_{2.5}$ were shown to occur. Measurements over Lake Erie verified model predictions of higher $\mathrm{O}_{3}$ over water that is most pronounced at night. However, there is considerable spatial heterogeneity over the lake, and while this high ozone can have acute effects when moving onshore, it is not greater than the reservoir of $\mathrm{O}_{3}$ found aloft at night. Thus, higher $\mathrm{O}_{3}$ over Lake Erie is not expected to have a major impact on the multi-day $\mathrm{O}_{3}$ budget in the region. The Lakes have a significant impact on the magnitude and location of pollutant peaks, which can have a greater impact in localized areas. Monitoring networks do not adequately capture these smallscale patterns and thus accurate models are needed to fill the gaps.

Vertical movement of air pollutants plays a significant role in the observed spatial patterns in the region. Aircraft-based measurements and detailed model simulations were critical for exploring these vertical motions. Some key identified features include the heat-island urban updraft circulation linked with downwind lake-induced subsidence, helical recirculation along shorelines and along the axis of lake breeze front convergence zones, and convective activity along lake breeze fronts. Classic 3-D lake breeze re-circulation patterns are typically difficult to observe due the influence of the synoptic winds. However, by focusing on a specific case study it was possible to demonstrate that enhancements in upward and downward motion at the Lake St. Clair front on the land and lake sides of the front do occur. The highresolution weather forecast model had success in simulating this behaviour to the extent of producing air movements consistent with a re-circulation pattern. Aircraft measurements showed that organic aerosol and sulfate formation rates were enhanced in this re-circulating air mass relative to the rates in the nearby regional background air. This demonstrates the importance of being able to accurately simulate vertical and horizontal lake-induced wind motions to realistically predict the degree of air mass aging and secondary pollutant formation in the region.

Given that the positioning of lake breeze fronts are on a finer scale than the currently available model resolution, we can expect difficulty in simulating the timing and location of these features and associated thunderstorm initiation over southwestern Ontario. Vertical velocities at fronts are underestimated in current models as a result of these limitations, hence affecting prediction accuracy for very local-scale pollutant movement. This can be expected to impact simulated pollutant fields, particularly the model ability to generate peaks in primary pollutant concentrations in areas of convergence and updrafts, thus affecting the production rates of secondary pollutants. It is evident that the spatial scale of meteorological features occurring over southwestern Ontario poses a significant challenge for accurate air quality and weather forecasting. Evaluation of the GEM high-resolution $(2.5 \mathrm{~km})$ runs demonstrated that the model could accurately predict general features such as lake breeze occurrence and degree of deformation under a variety of synoptic wind regimes. However, the simulated timing and location of lake breeze fronts and initiation of deep moist convection can differ substantially from the observed conditions. These weaknesses are not expected to have a major impact on model skill in predicting the magnitude of peak concentrations in $\mathrm{O}_{3}$ and 
providing insight into the complex spatial and temporal behaviour of air pollutants in the region, including relatively small-scale 3-D features of air pollutant transport. However, skill in predicting the location of peaks and the probability of interactions between convection, clouds and air pollutants will remain limited.

Sensitivity analyses from the models were highly informative. They helped identify problems with the emissions inventory, test subsequent improvements in spatial allocation and identify areas for improvement such as primary organic aerosol, black carbon and ammonia emissions. The improvements made to the inventory will help future model performance. Sensitivity analysis demonstrated that the magnitude of organic aerosol concentrations closer to the urban area increases with finer grid resolution, helping to reduce negative biases.

Mass tracking features employed in AURAMS were instrumental in identifying how the importance of the processes impacting $\mathrm{O}_{3}$ concentrations varied in time and space. These online sensitivity analyses pointed towards the suggestion that instantaneous $\mathrm{O}_{3}$ formation in southwestern Ontario is VOC-limited and that ozone formation has the greatest sensitivity to the chemistry and reactivity of aromatic compounds. However, the sensitivity of the daily maximum (1 and $8 \mathrm{~h}$ ) and longer-term statistics, such as the Canadawide Standard, for $\mathrm{O}_{3}$ to $\mathrm{NO}_{\mathrm{x}}$ and VOC still need to be tested in the model to rectify contrary $\mathrm{NO}_{\mathrm{x}}$ sensitivities in the domain using Sillman indicators. Determining the sources of $\mathrm{PM}_{2.5}$ is a high priority given the relevance to air quality management. Observation-based techniques were employed to capitalize on a variety of detailed aerosol and VOC measurements at the BAQS-Met ground sites as well as on the aircraft. While the main sources of inorganic secondary $\mathrm{PM}_{2.5}$ (nitrate, sulfate, ammonium) are well known, the model had difficulty predicting particle nitrate and particle acidity. There is a need to improve $\mathrm{NH}_{3}$ emissions by considering bi-directional flux and to improve predictions in free ammonia. Model predictions of temperature were also found to be important with overpredictions in nitrate arising when temperatures in the model are biased low.

Assessing the relative importance of anthropogenic versus biogenic VOCs in SOA formation continues to present a challenge. Despite the large flux of anthropogenic emissions in southwestern Ontario, biogenic VOCs were found to be an important contributor to SOA at Harrow, only $50 \mathrm{~km}$ southeast of Detroit/Windsor. In urban plumes, the SOA formation rate was found to be comparable to known photochemically active regions (i.e., Mexico City). Thus, while reducing anthropogenic precursors in the region will have a benefit, biogenic emissions will continue to contribute to local SOA formation. Interaction between particle sulfate and organic gases from both anthropogenic (gasoline vehicle exhaust) and biogenic (isoprene) sources was estimated through model applications and PMF, respectively, to contribute a significant amount of mass over the region. These processes remain poorly characterized, and while BAQSMet led to new insights regarding secondary particle formation and sources, our understanding remains limited. Consequently, the reliability of current air quality models for predictions of $\mathrm{PM}_{2.5}$ is relatively poor compared to $\mathrm{O}_{3}$ predictions, and hence their applications in detailed source apportionment studies and evaluation of emission control strategies targeting organic particles and particle nitrate need to take into account these uncertainties.

Acknowledgements. The authors thank Qian Li, Sabrina Li and Gang Lu from Environment Canada for assistance in preparation of this manuscript, Cris Mihele from Environment Canada for the Harrow ozone observations and Jonathan Abbatt and Jay Slowik from the University of Toronto for provision of the Harrow Aerosol Mass Spectrometer data. Funding for BAQS-Met was from Environment Canada, the Ontario Ministry of the Environment and the Natural Resources Canada Program on Energy Research and Development (PERD projects C11.008 and C12.007).

Edited by: J. W. Bottenheim

\section{References}

Barros, N., Borrego, C., Toll, I., Soriano, C., Jimenez, P., and Baldasano, J. M.: Urban photochemical pollution in the Iberian Peninsula: Lisbon and Barcelona Airsheds, J. Air Waste Manage., 53, 347-359, 2003.

Blumenthal, D. L., White, W. H., and Smith, T. B.: Anatomy of a Los Angeles smog episode: pollutant transport in the daytime sea breeze regime, Atmos. Environ., 12, 893-907, 1978.

Brook, J. R., Lillyman, C. D., Mamedov, A., and Shepherd, M.: Regional transport and urban contributions to fine particle $\left(\mathrm{PM}_{2.5}\right)$ concentrations in southeastern Canada, J. Air Waste Manage., 52, 174-185, 2002.

Brook, J. R., Strawbridge, K. B., Snyder, B. J., Boudries, H., Worsnop, D., Sharma, S., Anlauf, K. G., and Hayden, K. L.: Towards an understanding of the fine particle variations in the LFV: integration of chemical, physical and meteorological observations, Atmos. Environ., 38, 5775-5788, 2004.

Brook, J. R., Dann, T. F., Galarneau, E., Herod, D., and Charland, J. P.: The State of Air Quality in Canada: National Patterns, Chapter 3 in Air Quality Management: Canadian Perspectives on a Global Issue, edited by: Taylor, E. and McMillan, A., Springer, 2013.

Boucouvala, D. and Bornstein, R.: Analysis of transport patterns during an SCOS97-NARSTO episode, Atmos. Environ., 37, S73-S94, 2003.

Burrows, W. R. and Kochtubajda, B.: A decade of cloud-to-ground lightning in Canada: 1999-2008. Part 1: Flash density and occurrence, Atmos. Ocean, 48, 177-194, doi:10.3137/AO1118.2010, 2010.

Chan, T. W., Brook, J. R., Smallwood, G. J., and Lu, G.: Time-resolved measurements of black carbon light absorption enhancement in urban and near-urban locations of southern Ontario, Canada, Atmos. Chem. Phys., 11, 10407-10432, doi:10.5194/acp-11-10407-2011, 2011. 
Cheng, W. L.: Ozone distribution in coastal central Taiwan under sea-breeze conditions, Atmos. Environ., 36, 3445-3459, 2002.

Côté, J., Gravel, S., Méthot, A., Patoine, A., Roch, M., and Staniforth, A.: The operational CMC-MRB Global Environmental Multiscale (GEM) model. Part I: Design considerations and formulation, Mon. Weather Rev., 126, 1373-1395, 1998.

Dabek-Zlotorzynska, E., Dann, T. F., Martinelango, P. K., Celo, V., Mathieu, D., Ding, L., Austin, C., and Brook, J. R.: Canadian national air pollution surveillance (NAPS) $\mathrm{PM}_{2.5}$ speciation program: methodology and PM: chemical composition for the Years 2003 to 2008, Atmos. Environ., 45, 673-686, doi:10.1016/j.atmosenv.2010.10.024, 2011.

De Gouw, J. and Jimenez, J. L.: Organic aerosols in the Earth's atmosphere, Environ. Sci. Technol., 43, 7614-7618, doi:10.1021/es9006004, 2009.

Dickerson, R. R., Huffman, G. J., Luke, W. T., Nunnermacker, L. J., Pickering, K. E., Leslie, A. C. D., Lindsey, C. G., Slinn, W. G. N., Kelly, T. J., Daum, P. H., Delany, A. C., Greenberg, J. P., Zimmerman, P. R., Boatman, J. F., Ray, J. D., and Stedman, D. H.: Thunderstorms: An important mechanism in the transport of air pollutants, Science, 235, 460-465, 1987.

DSS Management Consultants: Health and environmental damages attributable to transboundary air pollution in Ontario, Ontario Ministry of the Environment, Report, Toronto, ON, 2005.

Eastman, J. L., Pielke, R. A., and Lyons, W. A.: Comparison of lakebreeze model simulations with tracer data, J. Appl. Meteor., 34, 1398-1418, 1995.

Ellis, R. A., Murphy, J. G., Markovic, M. Z., VandenBoer, T. C., Makar, P. A., Brook, J., and Mihele, C.: The influence of gasparticle partitioning and surface-atmosphere exchange on ammonia during BAQS-Met, Atmos. Chem. Phys., 11, 133-145, doi:10.5194/acp-11-133-2011, 2011.

Evtyugina, M. G., Nunes, T., Pio, C., and Costa, C. S.: Photochemical pollution under sea breeze conditions, during summer, at the Portuguese West Coast, Atmos. Environ., 40, 6277-6293, doi:10.1016/j.atmosenv.2006.05.046, 2006.

Fann, N., Lamson, A. D., Anenberg, S. A., Wesson, K., Risley, D., and Hubbell, B. J.: Estimating the national public health burden associated with exposure to ambient $\mathrm{PM}_{2.5}$ and ozone, Risk Anal., 32, 1-15, doi:10.1111/j.1539-6924.2011.01630.x, 2012.

Flagg, D. D. and Taylor, P. A.: Sensitivity of mesoscale model urban boundary layer meteorology to the scale of urban representation, Atmos. Chem. Phys., 11, 2951-2972, doi:10.5194/acp-11-29512011, 2011.

Fosco, T. and Schmeling, M.: Aerosol ion concentration dependence on atmospheric conditions in Chicago, Atmos. Environ., 40, 6638-6649, doi:10.1016/j.atmosenv.2006.05.061, 2006.

Garcia, V. C., Foley, K. M., Gego, E., Holland, D. M., and Rao, S. T.: A comparison of statistical techniques for combining modeled and observed concentrations to create high-resolution ozone air quality surfaces, J. Air Waste Manage., 60, 586-595, doi:10.3155/1047-3289.60.5.586, 2010.

Gong, W., Dastoor, A. P., Bouchet, V. S., Gong, S., Makar, P. A., Moran, M. D., Pabla, B., Ménard, S., Crevier, L.-P., Cousineau, S., and Venkatesh, S.: Cloud processing of gases and aerosols in a regional air quality model (AURAMS), Atmos. Res., 82, 248275, doi:10.1016/j.atmosres.2005.10.012, 2006.

Gordon, M., Staebler, R., Liggio, J., Makar, P., Brook, J., Li, S., Wentzell, J., Lu, G., and Lee, P.: Measurements of enhanced turbulent mixing near highways, J. Appl. Meteor. Climatol., 51, 1618-1632, 2012.

Government of Canada: Canadian Smog Science Assessment: Highlights and Key Messages, report Cat. no.: En88-5/2011EPDF, ISBN 978-1-100-19064-8, Her Majesty the Queen in Right of Canada, 2012.

Grossi, P., Thunis, P., Martilli, A., and Clappier, A.: Effect of Sea Breeze on Air Pollution in the Greater Athens Area. Part II: Analysis of Different Emission Scenarios, J. Appl. Meteor., 39, 563575, 2000.

Halla, J. D., Wagner, T., Beirle, S., Brook, J. R., Hayden, K. L., O’Brien, J. M., Ng, A., Majonis, D., Wenig, M. O., and McLaren, R.: Determination of tropospheric vertical columns of $\mathrm{NO}_{2}$ and aerosol optical properties in a rural setting using MAX-DOAS, Atmos. Chem. Phys., 11, 12475-12498, doi:10.5194/acp-1112475-2011, 2011.

Harris, L. and Kotomarthi, V. R.: Characteristics of the Chicago lake breeze and its effects on trace particle transport: Results from an episodic event simulation, J. Appl. Meteor., 44, 1637-165, doi:10.1175/JAM2301.1, 2005.

Hastie, D. R., Narayan, J., Schiller, C., Niki, H., Shepson, P. B., Sills, D. M. L., Taylor, P. A., Moroz, Wm. J., Drummond, J. W., Reid, N., Taylor, R., Roussel, P. B., and Melo, O.: Observational evidence for the impact of the lake breeze circulation on ozone concentrations in Southern Ontario, Atmos. Environ., 33, 323335, 1999.

Hayden, K. L., Macdonald, A. M., Gong, W., Toom-Sauntry, D., Anlauf, K. G., Leithead, A., Li, S.-M., Leaitch, W. R., and Noone, K.: Cloud processing of nitrate, J. Geophys. Res., 113, D18201, doi:10.1029/2007JD009732, 2008.

Hayden, K. L., Sills, D. M. L., Brook, J. R., Li, S.-M., Makar, P. A., Markovic, M. Z., Liu, P., Anlauf, K. G., O’Brien, J. M., Li, Q., and McLaren, R.: Aircraft study of the impact of lake-breeze circulations on trace gases and particles during BAQS-Met 2007, Atmos. Chem. Phys., 11, 10173-10192, doi:10.5194/acp-1110173-2011, 2011.

He, H., Tarasick, D. W., Hocking, W. K., Carey-Smith, T. K., Rochon, Y., Zhang, J., Makar, P. A., Osman, M., Brook, J., Moran, M. D., Jones, D. B. A., Mihele, C., Wei, J. C., Osterman, G., Argall, P. S., McConnell, J., and Bourqui, M. S.: Transport analysis of ozone enhancement in Southern Ontario during BAQS-Met, Atmos. Chem. Phys., 11, 2569-2583, doi:10.5194/acp-11-25692011, 2011.

Hedley, M., McLaren, R., Jiang, W., and Singleton, D. L.: Evaluation of an air quality simulation of the Lower Fraser Valley-II: Photochemistry, Atmos. Environ., 31, 1617-1630, 1997.

Hocking, W. K.: System design, signal-processing procedures, and preliminary results for the Canadian (London, Ontario) VHF atmospheric radar, Rad. Sci., 32, 687-706, 1997.

Jeong, C.-H., Evans, G. J., McGuire, M. L., Chang, R. Y.-W., Abbatt, J. P. D., Zeromskiene, K., Mozurkewich, M., Li, S.-M., and Leaitch, W. R.: Particle formation and growth at five rural and urban sites, Atmos. Chem. Phys., 10, 7979-7995, doi:10.5194/acp10-7979-2010, 2010.

Jeong, C.-H., McGuire, M. L., Godri, K. J., Slowik, J. G., Rehbein, P. J. G., and Evans, G. J.: Quantification of aerosol chemical composition using continuous single particle measurements, Atmos. Chem. Phys., 11, 7027-7044, doi:10.5194/acp-11-70272011, 2011. 
Jiang, W., Singleton, D. L., Hedley, M., and McLaren, R.: Sensitivity of ozone concentrations to $\mathrm{VOC}$ and $\mathrm{NO}_{\mathrm{x}}$ emissions in the Canadian Lower Fraser Valley, Atmos. Environ., 31, 627-638, 1997b.

Kambezidis, H. D., Weidauer, D., Melas, D., and Ulbricht, M.: Air Quality in the Athens Basin during Sea Breeze and nonSea Breeze days using Laser-Remote-Sensing Technique, Atmos. Environ., 32, 2173-2182, 1998.

King, P. and Sills, D. M. L.: The 1997 ELBOW Project: an experiment to study the Effects of Lake Breezes On Weather in southern Ontario, Preprints, 19th Conference on Severe Local Storms, Am. Meteorol. Soc., Minneapolis, MN, 317-320, 1998.

King, P. W. S., Leduc, M., Sills, D. M. L., Donaldson, N. R., Hudak, D. R., Joe, P. I., and Murphy, B. P.: Lake breezes in Southern Ontario and their relation to tornado climatology, Weather Forecast., 18, 795-807, 2003.

Lee, C. J., Brook, J. R., Evans, G. J., Martin, R. V., and Mihele, C.: Novel application of satellite and in-situ measurements to map surface-level $\mathrm{NO}_{2}$ in the Great Lakes region, Atmos. Chem. Phys., 11, 11761-11775, doi:10.5194/acp-11-11761-2011, 2011.

Levy, I., Dayan, U., and Mahrer, Y.: A five-year study of coastal recirculation and its effect on air pollutants over the East Mediterranean region, J. Geophys. Res., 113, D16121, doi:10.1029/2007JD009529, 2008.

Levy, I., Makar, P. A., Sills, D., Zhang, J., Hayden, K. L., Mihele, C., Narayan, J., Moran, M. D., Sjostedt, S., and Brook, J.: Unraveling the complex local-scale flows influencing ozone patterns in the southern Great Lakes of North America, Atmos. Chem. Phys., 10, 10895-10915, doi:10.5194/acp-10-10895-2010, 2010.

Li, S.-M., Liggio, J., Graham, L., Lu, G., Brook, J., Stroud, C., Zhang, J., Makar, P., and Moran, M. D.: Condensational uptake of semivolatile organic compounds in gasoline engine exhaust onto pre-existing inorganic particles, Atmos. Chem. Phys., 11, 10157-10171, doi:10.5194/acp-11-10157-2011, 2011.

Lu, R. and Turco, R. P.: Air pollutant transport in a coastal environment. Part I. Two dimensional simulations of sea-breeze and mountain effects, J. Atmos. Sci., 51, 2285-2308, 1994.

Lyons, W. A. and Cole, H. S.: Fumigation and plume trapping on the shores of Lake Michigan during stable onshore flow, J. Appl. Meteor., 12, 494-510, 1973.

Lyons, W. A. and Cole, H. S.: Photochemical oxidant transport mesoscale lake breeze and synoptic-scale aspects, J. Appl. Meteor., 15, 733-743, 1976.

Lyons, W. A. and Olsson, L. E.: Detailed mesometeorological studies of air pollution dispersion in the Chicago lake breeze, Mon. Weather Rev., 101, 387-403, 1973.

Lyons, W. A., Pielke, R. A., Tremback, C. J., Walko, R. L., Moon, D. A., and Keen, C. S.: Modeling impacts of mesoscale vertical motions upon coastal zone air pollution dispersion, Atmos. Environ., 29, 283-301, 1995a.

Lyons, W. A., Tremback, C. J., and Pielke, R. A.: Applications of the Regional Atmospheric Modeling System (RAMS) to provide input to photochemical grid models for the Lake Michigan Ozone Study (LMOS), J. Appl. Meteor., 34, 1762-1786, 1995b.

Ma, Y. and Lyons, T. J.: Recirculation of coastal urban air pollution under a synoptic scale thermal through in Perth, Western Australia, Atmos. Environ., 37, 443-454, 2003.

Makar, P. A., Gong, W., Mooney, C., Zhang, J., Davignon, D., Samaali, M., Moran, M. D., He, H., Tarasick, D. W., Sills, D., and
Chen, J.: Dynamic adjustment of climatological ozone boundary conditions for air-quality forecasts, Atmos. Chem. Phys., 10, 8997-9015, doi:10.5194/acp-10-8997-2010, 2010a.

Makar, P. A., Zhang, J., Gong, W., Stroud, C., Sills, D., Hayden, K. L., Brook, J., Levy, I., Mihele, C., Moran, M. D., Tarasick, D. W., He, H., and Plummer, D.: Mass tracking for chemical analysis: the causes of ozone formation in southern Ontario during BAQS-Met 2007, Atmos. Chem. Phys., 10, 11151-11173, doi:10.5194/acp-10-11151-2010, 2010b.

Markovic, M. Z., Hayden, K. L., Murphy, J. G., Makar, P. A., Ellis, R. A., Chang, R. Y.-W., Slowik, J. G., Mihele, C., and Brook, J.: The effect of meteorological and chemical factors on the agreement between observations and predictions of fine aerosol composition in southwestern Ontario during BAQS-Met, Atmos. Chem. Phys., 11, 3195-3210, doi:10.5194/acp-11-31952011, 2011.

McGuire, M. L., Jeong, C.-H., Slowik, J. G., Chang, R. Y.-W., Corbin, J. C., Lu, G., Mihele, C., Rehbein, P. J. G., Sills, D. M. L., Abbatt, J. P. D., Brook, J. R., and Evans, G. J.: Elucidating determinants of aerosol composition through particle-typebased receptor modeling, Atmos. Chem. Phys., 11, 8133-8155, doi:10.5194/acp-11-8133-2011, 2011.

McKendry, I. and Lundgren: Tropospheric layering of ozone in regions of urbanized complex coastal terrain: a review, Prog. Phys. Geogr., 24, 329-354, 2000.

McLaren, R., Wojtal, P., Majonis, D., McCourt, J., Halla, J. D., and Brook, J.: $\mathrm{NO}_{3}$ radical measurements in a polluted marine environment: links to ozone formation, Atmos. Chem. Phys., 10, 4187-4206, doi:10.5194/acp-10-4187-2010, 2010.

Millán, M. M., Salvador, R., Mantilla, E., and Artnano, B.: Meteorology and photochemical air pollution in Southern Europe: Experimental results from EC research projects, Atmos. Environ. 30, 1909-1924, 1996.

Millán, M. M., Mantilla, E., Salvador, R., Carratalá, A., Sanz, M. J., Alonso, L., Gangoiti, G., and Navazo, M.: Ozone cycles in the western Mediterranean basin: interpretation of monitoring data in complex coastal terrain, J. Appl. Meteor., 39, 487-508, 2000.

NARSTO: Improving Emission Inventories for Effective Air Quality Management Across North America: A NARSTO Assessment, NARSTO-05-001, Oak Ridge, TN, 2005.

Nuaaman, I., McLaren, R., Ng, A., Kornilova, A., and Moukhtar, S.: Measurements of Gaseous Carbonyls Using an Automated HPLC system during the BAQS-MET Field Study, American Geophysical Union, Fall Meeting 2008, \#A41F-0175, 2008AGUFM.A41F0175N, 2008.

Ontario, Air Quality in Ontario 2004 Report, available at: http://www.ene.gov.on.ca/environment/en/resources/STD01_ 076444.html, 2005.

Ontario, Air Quality in Ontario 2005 Report, available at: http://www.ene.gov.on.ca/environment/en/resources/STD01_ 076445.html, 2006.

Ontario, Air Quality in Ontario 2006 Report, available at: http://www.ene.gov.on.ca/environment/en/resources/STD01_ 076446.html, 2007.

Parrish, D. D., Allen, D. T., Bates, T. S., Estes, M., Fehsenfeld, F. C., Feingold, G., Ferrare, R., Hardesty, R. M., Meagher, J. F., Nielsen-Gammon, J. W., Pierce, R. B., Ryerson, T. B., Seinfeld, J. H., and Williams, E. J.: Overview of the Second Texas Air Quality Study (TexAQS II) and the Gulf of Mexico Atmospheric 
Composition and Climate Study (GoMACCS), J. Geophys. Res., 114, D00F13, doi:10.1029/2009JD011842, 2009.

Reid, N. W., Niki, H., Hastie, D. R., Shepson, P. B., Roussel, P., Melo, O., Mackay, G., Drummond, J., Schiff, H. I., Poissant, L., and Moroz, W.: The southern Ontario oxidant study: Overview and case studies for 1992, Atmos. Environ., 30, 2125-2132, 1996.

Robichaud, A. and Ménard, R.: Multi-year objective analyses of warm season ground-level ozone and PM2.5 over North America using real-time observations and Canadian operational air quality models, Atmos. Chem. Phys. Discuss., 13, 13967-14035, doi:10.5194/acpd-13-13967-2013, 2013.

Seaman, N. L. and Michelson, S. A.: Mesoscale meteorological structure of a high-ozone episode during the 1995 NARSTONortheast study, J. Appl. Meteor., 39, 384-398, 1998.

Sillman, S.: The use of $\mathrm{NO}_{y}, \mathrm{H}_{2} \mathrm{O}_{2}$, and $\mathrm{HNO}_{3}$ as indicators for ozone- $\mathrm{NO}_{\mathrm{x}}$-hydrocarbon sensitivity in urban locations, J. Geophys. Res., 100, 14175-14188, 1995.

Sillman, S., Samson, P. J., and Masters, J. M.: Ozone formation in urban plumes transported over water: photochemical model and case studies in the northeastern and midwestern U.S., J. Geophys. Res., 98, 12687-12699, 1993.

Sills, D., Taylor, P., King, P., Hocking, W., and Nichols, I.: ELBOW 2001- Studying the relationship between lake breezes and severe weather: project overview and preliminary results. Proceedings 21st Severe Local Storms Conference, San Antonio, TX, Am. Meteorol. Soc., 611-614, 2002.

Sills, D. M. L.: Lake and land breezes in southwestern Ontario: observations, analyses and numerical modelling, Ph.D. dissertation, CRESS, York University, 338 pp., 1998.

Sills, D. M. L., Brook, J. R., Levy, I., Makar, P. A., Zhang, J., and Taylor, P. A.: Lake breezes in the southern Great Lakes region and their influence during BAQS-Met 2007, Atmos. Chem. Phys., 11, 7955-7973, doi:10.5194/acp-11-7955-2011, 2011.

Slowik, J. G., Stroud, C., Bottenheim, J. W., Brickell, P. C., Chang, R. Y.-W., Liggio, J., Makar, P. A., Martin, R. V., Moran, M. D., Shantz, N. C., Sjostedt, S. J., van Donkelaar, A., Vlasenko, A., Wiebe, H. A., Xia, A. G., Zhang, J., Leaitch, W. R., and Abbatt, J. P. D.: Characterization of a large biogenic secondary organic aerosol event from eastern Canadian forests, Atmos. Chem. Phys., 10, 2825-2845, doi:10.5194/acp-10-2825-2010, 2010.

Slowik, J. G., Brook, J., Chang, R. Y.-W., Evans, G. J., Hayden, K., Jeong, C.-H., Li, S.-M., Liggio, J., Liu, P. S. K., McGuire, M., Mihele, C., Sjostedt, S., Vlasenko, A., and Abbatt, J. P. D.: Photochemical processing of organic aerosol at nearby continental sites: contrast between urban plumes and regional aerosol, Atmos. Chem. Phys., 11, 2991-3006, doi:10.5194/acp-11-29912011, 2011.
Sjostedt, S. J., Slowik, J. G., Brook, J. R., Chang, R. Y.-W., Mihele, C., Stroud, C. A., Vlasenko, A., and Abbatt, J. P. D.: Diurnally resolved particulate and VOC measurements at a rural site: indication of significant biogenic secondary organic aerosol formation, Atmos. Chem. Phys., 11, 5745-5760, doi:10.5194/acp-11-57452011, 2011.

Smoydzin, L., Fnais, M., and Lelieveld, J.: Ozone pollution over the Arabian Gulf - role of meteorological conditions, Atmos. Chem. Phys. Discuss., 12, 6331-6361, doi:10.5194/acpd-126331-2012, 2012.

Strawbridge, K. B. and Snyder, B. J.: Planetary boundary layer height determination during Pacific 2001 using the advantage of a scanning lidar instrument, Atmos. Environ., 38, 5861-5871, 2004.

Steyn, D. G., Bottenheim, J. W., and Thomson, R. B.: Overview of tropospheric ozone in the Lower Fraser Valley, and the Pacific '93 field study, Atmos. Environ., 31, 2025-2036, 1997.

Stroud, C. A., Makar, P. A., Moran, M. D., Gong, W., Gong, S., Zhang, J., Hayden, K., Mihele, C., Brook, J. R., Abbatt, J. P D., and Slowik, J. G.: Impact of model grid spacing on regionaland urban- scale air quality predictions of organic aerosol, Atmos. Chem. Phys., 11, 3107-3118, doi:10.5194/acp-11-31072011, 2011.

Stroud, C. A., Moran, M. D., Makar, P. A., Gong, S., Gong, W., Zhang, J., Slowik, J. G., Abbatt, J. P. D., Lu, G., Brook, J. R., Mihele, C., Li, Q., Sills, D., Strawbridge, K. B., McGuire, M. L., and Evans, G. J.: Evaluation of chemical transport model predictions of primary organic aerosol for air masses classified by particle component-based factor analysis, Atmos. Chem. Phys., 12, 8297-8321, doi:10.5194/acp-12-8297-2012, 2012.

Wentzell, J. J. B., Schiller, C. L., and Harris, G. W.: Measurements of HONO during BAQS-Met, Atmos. Chem. Phys., 10, 12285 12293, doi:10.5194/acp-10-12285-2010, 2010.

Zhang, J., Zheng, Q., Moran, M. D., Gordon, M., Liggio, J., Makar, P., Taylor, B., and Stroud, C.: Improvements to SMOKE Processing of Canadian On-Road Mobile Emissions, 2012 International Emission Inventory Conference, Tampa, Florida, http://www.epa.gov/ttn/chief/conference/ei20/session1/ jzhang.pdf, 13-16 August 2012. 